\title{
Erectile dysfunction and the biochemical/molecular/ regulation of human penile arteries
}

\author{
Ph.D. Thesis
}

Előd István Király M.D.

Department of Urology, Faculty of Medicine, University of Szeged, Szeged, Hungary 


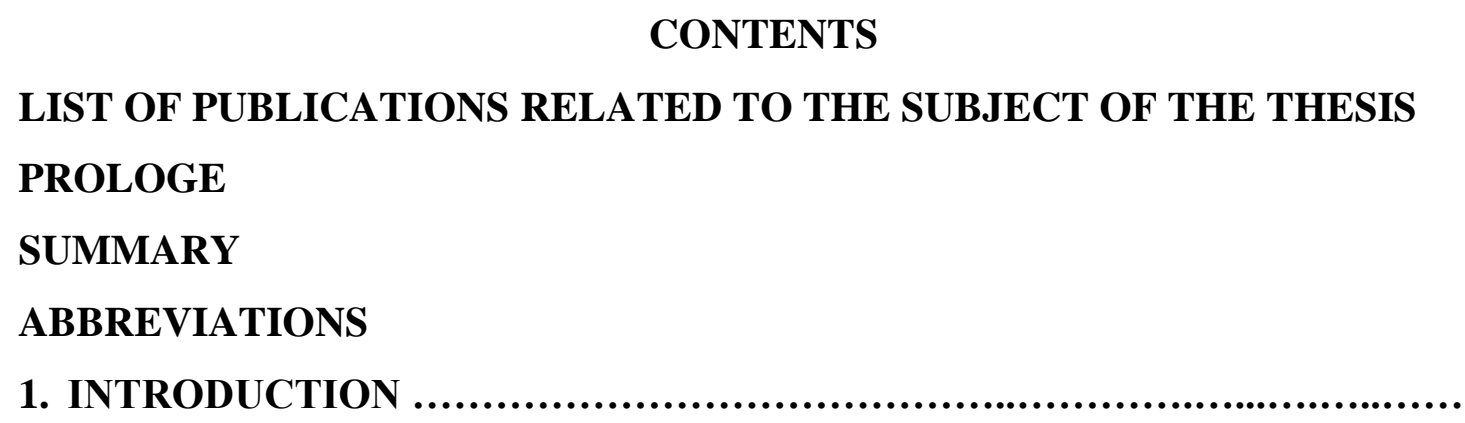

1.1. Physiology of penile erection

1.1.1. Central regulation

1.1.2. Peripheral regulation

1.1.2.1.Physiological regulation of penile vasoconstriction

1.1.2.2.Physiological regulation of penile vasodilatation

1.1.2.3.Intracellular pathways involved in erection

\subsection{Pathophysiology of erectile dysfunction}

\subsection{Aims of the present study}

\section{METHODS}

\subsection{Indirect clinical investigation of human penile arteries}

2.1.1. Measurment of flow-mediated dilation

2.1.1.1. Patients

2.1.1.2. Experimental procedure

\subsection{INVESTIGATION OF HUMAN PENILE ARTERIES}

2.2.1. Transsexual operations - source of penile arteries

2.2.2. Measurement of isometric tension in human intracavernosus arteries

2.2.2.1.Tissue preparation and mounting

2.2.2.2.Experimental procedure

2.2.2.3.Data analysis and statistical comparisons

2.2.2.4.Drugs used in the study

\subsection{Ethics}

2.3.1. Transsexual operations

2.3.2. Investigations of flow mediated dilation

\subsection{Analysis}

2.4.1. Analyses of flow mediated dilation 
2.4.2. Analysis of isometric tension measurements

\subsection{Drugs and other agents}

\section{RESULTS}

\subsection{INVESTIGATION OF FLOW-MEDIATED DILATATIONS IN VIVO ...}

3.1.1. Patients characteristics

3.1.2. Effect of age and smoking on flow-mediated dilation

3.1.3. Effect of body-mass index, cholesterol and triglyceride level on flow-mediated dilation

\subsection{INVESTIGATION OF VASCULAR RELAXATION IN VITRO}

3.2.1. Investigation of endothelium-dependent relaxation

3.2.1.1.Determination of the role of EDH in ACh-evoked relaxation

3.2.1.2.Effect of blockers of the EDH pathway on ACh relaxation

3.2.2. Investigation of endothelium-independent relaxation

3.2.2.1. Characterization of CNP-evoked relaxation

3.2.2.2.Effect of IbTX on SNP-induced relaxation

\section{DISCUSSION}

4.1. Changes in surgical technique in transsexual operation

4.2. Flow-mediated dilation and erectile dysfunction

4.3. Importance of EDH in erectile function

4.4. $\mathrm{CNP}$ and $\mathrm{EDH}$ in penile arteries

4.5. Importance of $\mathrm{BK}_{\mathrm{Ca}}$ channels in erectile function

4.6. $\mathrm{BK}_{\mathrm{Ca}}$ channel as target for the treatment of erectile dysfunction

5. REFERENCES

6. ACKNOWLEDGEMENTS

7. ANNEX 


\section{List of full papers related to the subject of the thesis}

I. Kiraly I, Pataricza J, Bajory Z, Simonsen U, Varro A, Papp JG, Pajor L, Kun A Involvement Of Large-Conductance $\mathrm{Ca}(2+)$-Activated $\mathrm{K}(+)$ Channels In Both Nitric Oxide And Endothelium-Derived Hyperpolarization-Type Relaxation In Human Penile Small Arteries

BASIC \& CLINICAL PHARMACOLOGY \& TOXICOLOGY 113:(1) pp. 19-24. (2013)

II. Király I, Kun A, Pajor L

A merevedés kialakulásának sejtszintü mechanizmusa, különös tekintettel a magas konduktanciájú Ca2+ aktiválta $\mathrm{K}+$ csatornák ebben játszott szerepére.

MAGYAR ANDROLÓGIA 15: p. 64. (2010)

III. Király I., Pajor L.

Mütéttechnikai újítások transzszexuális férfi-nő átalakító mütétek kapcsán

Magyar Urológia 22,3: 143-144. (2010)

IV. Kun A, Király I, Varró A, Simonsen U, Pataricza J, Papp JGy, Pajor L

Endothelium in health and disease involvement of large-conductance $\mathrm{Ca} 2+-$ activated $\mathrm{K}+$ SSEP

BASIC \& CLINICAL PHARMACOLOGY \& TOXICOLOGY 107:(Suppl.1) p. 396. (2010)

V. Jebelovszky É, Király I, Török L, Deák G, Bajory Z, Forster T, Pajor L, Varga A A kari verőér rugalmasságának mérése merevedési zavarban MAGYAR UROLÓGIA 20:(1) pp. 13-17. (2008)

VI. Kun A, Király I, Pataricza J, Márton Z, Krassói I, Varró A, Simonsen U, Papp JGY, Pajor L

C-type natriuretic peptide hyperpolarizes and relaxes human penile resistance arteries JOURNAL OF SEXUAL MEDICINE 5:(5) pp. 1114-1125. (2008) 
VII. Király I, Kun A, Pataricza J, Márton Z, Krassói I, Varró A, Papp JGy, Pajor L A C-típusú natriuretikus peptid hatásának vizsgálata humán pénisz rezisztenciaéren MAGYAR UROLÓGIA 18: pp. 107-112. (2006)

VIII. Kun A, Király I, Márton Z, Krassói I, Pataricza J, Varró A, Simonsen U, Papp JGy, Pajor L

Investigation of the relaxant effect of C-type natriuretic peptide (CNP) in human penile small arteries

ACTA PHARMACOLOGICA SINICA 27: p. 194. (2006)

IX. Kun A, Király I, Márton Z, Krassói I, Pataricza J, Varró A, Simonsen U, Pajor L, Papp JGy

C-type natriuretic peptide is an endothelium-derived hyperpolarizing factor in human penile resistance arteries

JOURNAL OF SEXUAL MEDICINE -: p. 4. (2006)

Cumulative impact factor: 7,687

\section{PROLOGUE}

Sexuality is the result of complex effect of biological, psychological, socioeconomic, cultural ethical, spiritual and religious interactions.

Erection is the symbol of our age. The symbol of our achievement oriented world. Heart, as emotion, faith, patience, understanding, self sacrifice and forgiveness was exchanged by the steel lustering sense, cunnig, egoism, and desire of power. With the change of classical male and female roles a greater and greater pressure is on men to be able to meet the determined expectations of their partner. The first sexual intercourse is frequently made with the lack of proper level psychic development and in the case of their eventual failure the further development of young men is hindered. Does high tech make our life easier or does it increase the number of executable tasks at a given time? There is no time for regeneration, intimacy, but you have to perform! At the same time it is inevitable that there is no harmonious relationship without good sexual life. 
Reproduction is unimaginable without natural erection. Satisfactory erection, as our language says, is unique in living nature, to make pleasure to a partner, creating and sustaining a physical and psychical relationship with the partner, creating the most effectively operating micro unity in the society, the family

To sum up, erection is more than a physiological process, an indispensable part of our survival and quality of life.

\section{SUMMARY}

1. Flow mediated vasodilation as a new, non-invasive diagnostic procedure in the examination of vascular type erectile dysfunction.

2. CNP has a strong vasodilatation effect on human resistance vessels in the presence of NO synthase and cyclooxygenase enzyme inhibitors

3. That relaxation demonstrates a similar characteristics as an EDHF released by Ach

4. CNP has a smooth muscle cells hyperpolarization effect similar to Ach

5. Our examinations prove CNP is an EDHF in human penile resistance vessels which plays an essential role in the reduction of vessel tone supporting erection.

6. CNP or its similar compounds may be successful in the treatment of erectile dysfunction.

7. NO and EDHF take part in the endothelium dependence relaxation human penile intracavernosus arteries.

8. BKC channels play an essential role in the establishment of the effect enduced by both of NO and EDHF

9. During our examination the opening compounds of BKC channels are assumed to be effective in the treatment of disregulation of penile arteries.

10. The Hungarian implementation of female to male sexual reassignment operation

Development of the surgical technique in our Department of Urology has lead to better functional and esthetical results. These modifications are the following

-The turned down u-shape perineal incision was exchanged by median sagittal incision

- The expert preparation of neurovascular bundle 
- Reaching clitoral orgasm a greater part of the glans is used at the creation of clitoris, one part of it is deepithelialized and it is sunk under the skin. The fixing sutures of the neo clitoris is placed into foreskin to avoid circular damage.

\section{Abbrevation}

Ach-acetylcholine

A II- angiothensin II

BKCa-large conductance $\mathrm{Ca}$ activated $\mathrm{K}$ channel

BMI-body mass index

CNP- C type natriuretic peptid

CVD-cardiovascular disease

DMSO-dimethyl sulfoxide

ECG-electrocardiography

ED-erectile dysfunction

ETs-endothelins

EDHF-endothel derived hyperpolarization factor

FSH: follicle stimulating hormone

FMD-flow mediated vasodilatation

GC-guanilate cyclase

HDL-high density lipoprotein

HGB-hemoglobin

HTC-hematocrit

IbTX-iberiotoxin

IIEF-International Index of Erectile Function

IKCa-intermediate conductance $\mathrm{Ca}$ activated $\mathrm{K}$ channel

LDL-low density lipoprotein

LH-luteinizing hormone

MMAS-Massachusetts Male Aging Study

MPOA-medial preoptic area

MLCP-myosin light-chain phosohatase

NANC-non-adrenergic non-cholinergic 
NO-nitrogen -oxide

NOS-nitric oxide synthase

nNOS-neuronal nitrogen-oxide synthase

PET-positron emission tomography

PGE1-prostaglandin E1

PGE2-prostaglandin E2

PVN-paraventricular nucleus

SEM-standard error of the mean

SK-small conductance $\mathrm{Ca}$ activated $\mathrm{K}$ channel

VACht-vesicular acetylcoline transporter

\section{INTRODUCTION}

\subsection{Physiology of penile erection}

Erection is a hemodynamic event where vasodilatation of intracavernous and helicine arteries is followed by increased arterial blood inflow to the corpora cavernosa. Erection involves different central and peripheral neural and/or humoral mechanisms. During these processes activation of parasympathetic pelvic nerves leads to arterial dilatation and to initiation of erection while flow stimulation of the endothelium in the penis contributes to the sustained vasodilatation during erection. Although some steps of pathways involved in erection still remains less clear, balance between contraction and relaxation of arterial and cavernosal smooth muscle cells determines flaccidity and erection, the functional states of the penis $[1-3]$.

\subsubsection{Central regulation}

Evidences from animal studies indicate that oxytocinergic neurons originating in the paraventricular nucleus (PVN) of the hypothalamus and projecting to several extrahypothalamic brain areas (e.g., hippocampus, pons, medulla oblongata and spinal cord) control penile erection. In addition to PVN, medial amygdala, medial preoptic area (MPOA), the periaqueductal gray, and ventral tegmentum are also recognized as key structures in the 
central control of the male sexual response. Nerves travel from the brain through the spinal cord to the genital apparatus which is innervated mainly by pudendal and cavernosal nerves. Pudendal nerves originate from the sacral tract of the spinal cord and contain the primary afferent sensory and motor pathways to the penis. Cavernosal nerves, which contain the primary efferent sympathetic and parasympathetic pathways originating in the pelvic plexuses. These are innervated by hypogastric nerves, which originate in the thoracic-lumbar tract of the spinal cord, by pelvic nerves which originate in the sacral tract of the spinal cord, and by post-gangliar fibers, which originate from the paravertebral sympathetic ganglia chain of the thoracic-lumbar tract of the spinal cord $[4,5]$.

Many central neurotransmitters and neuropeptides control penile erection. They can either facilitate (nitric oxide (NO), oxytocin, dopamine, glutamic acide, acetylcholine, ACTH, MSH peptides, hexarelin peptides, pro-VGF peptides) or inhibit (GABA, noradrenaline, opioid peptides, endocannabinoids) penile erection by acting in several brain areas. Serotonin can exert both facilitatory and inhibitory effect, depending on the receptor subtype involved. Among neurotransmitters and neuropeptides, oxytocin and nitric oxide seem to be main players in the mediation of the effect. The activation of oxytocinergic neurons follows the activation of nitric oxide synthase (NOS) present in these neurons. The NO-mediated activation of oxytocinergic neurons is apparently not related to the stimulation of guanylyl cyclase; it causes release of oxytocin in the spinal cord and in extrahypothalamic brain areas. In the mediation of erection, androgens play also an important role; lack of testosterone may reduce or abolish the effects of many of the erection-mediating transmitters $[1,5]$.

\subsubsection{Peripheral regulation}

The main arterial supply to the penis is via the internal pudendal artery that branches off the hypogastric artery and splits into bulbourethral, dorsal and cavernosal arteries. While the bulbourethral artery supplies the urethra and the glans, the paired dorsal penile arteries supply superficial structures in the penis $[2,3]$. The cavernous arteries penetrate the tunica albuginea and enter the corpora cavernosa to give the helicine arteries, that open directly into and feed the cavernous spaces, acting as resistance arteries [6]. Sympathetic, parasympathetic and non-adrenergic non-cholinergic (NANC) nerves, which enter the corpora cavernosa, corpus spongiosum, and glans penis, regulate blood flow during erection and 
detumescence. Imbalance between contractile and relaxant factors in the corpus cavernosum and penile arteries is one of the main causes of organic erectile dysfunction (ED) [7] .

\subsubsection{Physiological regulation of penile vasoconstriction}

In the absence of sexual stimulation, intracorporal smooth muscle is maintained in semicontracted state, called detumescence or flaccid state. This constriction is the result of intrinsic myogenic activity, sympathetic activity and vasoconstrictors.

Myogenic tone of small arteries is characterised by an increased vasoconstriction in response to an enhanced intravascular pressure and, conversely, dilation to a reduction in pressure [8]. The role of the myogenic response in the regulation of penile vascular resistance is largely unknown. Penile small arteries exhibit myogenic activity in vitro in the form of increased tone that is enhanced by inhibition of nitric oxide synthase (NOS) and cyclo-oxygenase, as well as blockers of $\mathrm{Ca}^{2+}$-activated $\mathrm{K}^{+}$channels, thus suggesting that basal release of $\mathrm{NO}$ and prostanoids, and basal $\mathrm{Ca}^{2+}$-activated $\mathrm{K}^{+}$channel activity oppose the myogenic contraction [9-11]. These results are in contrast to those in corpus cavernosum where inhibition of cyclo-oxygenase abolishes basal myogenic activity in vitro [2] .

Penile smooth muscle receives a rich sympathetic innervation, and adrenergic nerves are responsible for the detumescence of the erect penis and also contribute to the maintenance of the flaccid state through the tonic release of noradrenaline. Adrenergic stimuli cause contraction of corporal arterial smooth muscle, which leads to the reduction of arterial inflow $[2,12,13]$. Both $\alpha_{1}-$ and $\alpha_{2}$ - adrenergic receptors have been demonstrated in human CC tissue, but postjunctional $\alpha 1$ - adrenergic receptors are responsible for contraction, whereas prejunctional $\alpha_{2}$ - adrenergic receptors may down-regulate both noradrenaline and NO release [14].

Role of different vasocontractile factors has been demonstrated in regulation of penile vasoconstriction. Penile erectile tissues synthesize and locally metabolize several contractile prostanoids (e.g. PGF2 $\alpha$ and thromboxane A2), which are involved in the maintenance of the myogenic spontaneous tone [15]. Endothelins (ETs) are potent vasoconstrictor peptides synthesized by endothelial cells that have been reported to induce contraction of erectile tissues and play a role in maintainance of corpus cavernosum smooth muscle tone. Endothelin receptors have been isolated in both endothelial and smooth muscle cells of human corpus 
cavernosum $[16,17]$. Angiotensin II (AII) is locally formed in the endothelial and smooth muscle cells of the penile corpus cavernosum. Its contractile effect is mediated by muscular AT 1 receptors and increased level of AII has been demonstrated in cavernous blood during detumescence $[18,19]$.

\subsubsection{Physiological regulation of penile vasodilatation}

On sexual stimulation, penile erection is initiated by activation of parasympathetic pelvic nerves leading to penile arterial dilatation. Relaxation of the erectile smooth muscle elements of the corpora cavernosa (trabecular smooth muscle) then follows, allowing blood filling of the sinoids and restriction of the venous outflow, with entrapment of pressurised blood in the corpora cavernosa. In this process, release of neurotransmitters from the cavernous nerve terminals and of relaxing factors from the endothelial cells in the penis lead to the relaxation of both arterial and cavernousal smooth muscle cells [3] .

According to the classic theory of autonomic neurotransmission, the neurotransmitter released from the sacral parasympathetic nerves supplying penis was believed to be acetylcholine (ACh), but now it is widely accepted that nitric oxide (NO) is the neurotransmitter mediating the vasodilatation and relaxation of corpus cavernosum leading to erection. ACh released from cholinergic nerves probably acts on prejunctional muscarinic receptors at sympathetic nerve terminals to inhibit noradrenaline release thereby decreasing sympathetic adrenergic tone [2] .

A large amount of evidence suggests that $\mathrm{NO}$ is the principal transmitter mediating penile erection, which can be released from both nerve endings and endothelial cells. Neuronal NO synthase (nNOS) has been found in the pelvic plexus and in terminal branches of the cavernous nerves innervating the trabecular smooth muscle and penile vasculature $[20,21]$. nNOS and vesicular ACh transporter (VAChT) are co-localized in most nerve terminals surrounding penile small arteries which suggests that ACh and NO coexist in the same parasympathetic neurons that control penile arterial tone $[22,23]$. In addition to parasympathetic nerves, non-adrenergic non-cholinergic (NANC) nerves also mediate relaxation of the trabecular smooth muscle via the release of neuronal NO [2] .

There is a rich presence of peptidergic nerves containing vasoactive intestinal peptide (VIP) in the penis and nNOS, VIP and VAChT are co-localized in the same perivascular 
nerve terminals around penile arteries and in trabecular smooth muscle $[22,23]$. It has also been suggested that ATP is a NANC transmitter in the CC and that purinergic transmission may be an important component involved in the initiation and maintenance of penile erection $[24,25]$. The detailed role of VIP and ATP in erectile function needs further investigations.

Endothelial cells, which are in contact with both blood and smooth muscle cells, play a key role in the regulation of the underlying vascular tone and homeostasis. The endothelium interacts with smooth muscle cells by the synthesis and secretion of vasorelaxant mediators, like NO and prostanoids, and it is involved in the endothelium derived hyperpolarization $(\mathrm{EDH})$ - type relaxation.

eNOS is present in the endothelium lining the cavernous sinusoids and penile blood vessels, and endothelial-derived NO is produced in the penis by activation of eNOS in response to either hemodynamic stimuli, like shear stress generated by increased blood flow or neurohumoral factors such as ACh, acting on specific endothelial receptors $[20,26]$. It is believed that neuronal NO released from parasympathetic and NANC nerves leads to arterial dilatation and to initiation of erection while endothelial NO released by flow stimulation of the endothelium in the penis contributes to the sustained vasodilatation during erection $[1,27]$.

Relaxant prostanoids may be synthesized by both smooth muscle and endothelial cells and $\mathrm{PGE}_{1}$ and $\mathrm{PGE}_{2}$ being primarily produced in penile smooth muscle and $\mathrm{PGI}_{2}$ in the vascular endothelium. A basal release of relaxant prostanoids is involved in the maintenance of penile arteriolar tone in human penile resistance arteries $[15,28,29]$.

In human penile small arteries there is a significant relaxation evoked by endotheliumdependent agonists, which is resistant to blockade of NOS and cyclooxygenase [30]. This non-NO non-prostanoid endothelial factor was first reported in systemic arteries and associated with hyperpolarization of arterial smooth muscle thereby being referred to as endothelium derived hyperpolarization $(\mathrm{EDH})$ [31]. In the systemic circulation, there is a correlation between vessel size and the relative contribution of NO to the endotheliumdependent vasodilatations, the smaller the artery, the larger the component of the relaxation resistant to NOS blockade [32]. Although the EDH-type relaxation is present in human penile arteries $[30,33]$, different mechanisms and candidates may contribute to EDH-type 
vasodilation [31]. In systemic arteries several candidates for EDHF have been suggested, including potassium ions [34], products of the cytochrome P450 pathway [35-38], C-type natriuretic peptide (CNP) [39], and, controversially, hydrogen peroxide [40,41] .

\subsubsection{Intracellular pathways involved in erection}

Endothelium-dependent vasodilatation, induced by shear stress or agonists, results from membrane hyperpolarization and the subsequent increase in intracellular $\mathrm{Ca}^{2+}$ level $\left(\left[\mathrm{Ca}^{2+}\right]_{\mathrm{i}}\right)$ of the endothelial cell. This increase in $\left[\mathrm{Ca}^{2+}\right]_{\mathrm{i}}$ activates eNOS and leads to the production and release of endothelium-dependent vasodilators such as; NO, prostacyclin $\left(\mathrm{PGI}_{2}\right)$, or induced EDH-type relaxation. The endothelial cell membrane potential is regulated by several ion channels, including $\mathrm{Ca}^{2+}$-activated $\mathrm{K}^{+}$channels $\left(\mathrm{K}_{\mathrm{Ca}}\right)$. Small- and intermediate conductance $\mathrm{Ca}^{2+}$-activated $\mathrm{K}^{+}$channels $\left(\mathrm{SK}_{\mathrm{Ca}}\right.$ and $\left.\mathrm{IK}_{\mathrm{Ca}}\right)$, located in endothelial cells, are strictly $\mathrm{Ca}^{2+}$ sensitive and have key roles in release of vasodilator substances. NO, released from nerve endings or endothelial cells, diffuses into smooth muscle cells to activate guanylate cyclase (GC). Increased cGMP levels in smooth muscle activate protein kinase $\mathrm{G}$ $(\mathrm{PKG})$, which can either stimulate large conductance $\mathrm{Ca}^{2+}$-activated $\mathrm{K}^{+}$channels $\left(\mathrm{BK}_{\mathrm{Ca}}\right)$ and reduce intracellular $\mathrm{Ca}^{2+}$, or phosphorylate myosin light-chain phosphatase (MLCP) and reduce $\mathrm{Ca}^{2+}$ sensitivity $[1,14,42]$.

$\mathrm{BK}_{\mathrm{Ca}}$ channels are located in smooth muscle cells and are both $\mathrm{Ca}^{2+}$ and voltagesensitive. The $\mathrm{BK}_{\mathrm{Ca}}$ channel seems to be an important convergence point in modulating the degree of corporal smooth muscle contraction. The activity of this channel is increased after cellular activation of cGMP or cAMP pathway. NO/cGMP can activate $\mathrm{BK}_{\mathrm{Ca}}$ channels directly through S-nitrosylation or indirectly through PKG $[43,44]$, while PGE 1 /cAMP can activate $\mathrm{BK}_{\mathrm{Ca}}$ channels through protein kinase $\mathrm{A}$ (PKA) [45]. The resulting hyperpolarization, in turn, is coupled to decreased transmembrane calcium flux through Ltype voltage-dependent $\mathrm{Ca}^{2+}$ channels and, ultimately, smooth muscle relaxation [46]. In contrast to $\mathrm{PKG}$ and $\mathrm{PKA}$, protein kinase $\mathrm{C}$ can depress the $\mathrm{BK}_{\mathrm{Ca}}$ channel activity and this inhibitory effect is involved in vasoconstriction induced by 5-hydroxytryptamine, angiotensin II and phenylephrine [47].

The intracellular level of second messenger cAMP and cGMP is regulated by phosphodiesterase isoenzymes (PDEs). The protein superfamily of cyclic nucleotide PDEs 
can be subdivided into at least 11 families of structurally and functionally related enzymes, however three of the PDE families (PDEs 5, 6, 9) are considered to be "cGMP-specific PDEs" [48]. In penile smooth muscle the cGMP-specific cGMP binding PDE5 is the main cGMP catalyzing enzyme. PDE5 is abundant in the smooth muscle layer of both human penile arteries and in human corpus cavernosum, and it is a target for pharmacological intervention in the treatment of $\operatorname{ED}[49,50]$.

\subsection{Pathophysiology of erectile dysfunction}

DEFINITION OF ERECTILE DYSFUNCTION The consensus panel definition of erectile dysfunction, formerly termed impotence, is as follows: Erectile dysfunction is the persistent or repeated inability for 3 months duration or more to attain and/or maintain an erection sufficient for satisfactory sexual performance (51) The definition is based upon the patient's self-report in conjunction with medical, psychosocial, and sexual history assessments. Duration criteria may be modified under special circumstances (e.g., postprostatectomy).

The Massachusetts Male Aging Study (MMAS) identified a prevalence of ED in 52\% of men aged 40-70 years and with higher rates in those older than 70 years, and the likely worldwide increase in the prevalence of ED has also been described $[52,53]$. ED can be classified into four different types: psychogenic, vasculogenic/organic, neurologic, and endocrinologic ED, although two other categories, the drug induced and iatrogenic ED, are also often involved in this classification $[1,54]$. The most common cause for ED is vasculogenic, this was found to account for approximately $75 \%$ of patients with ED [51] .

Common risk factors associated with generalized penile arterial insufficiency include ageing, hypertension, hyperlipidemia, cigarette smoking, overweight and diabetes mellitus. Persons with type 2 diabetes mellitus have a threefold greater risk of ED compared with the general population [55]. Endothelial dysfunction is common sign in cardiovascular diseases (hypertension, atherosclerosis, smoking, and diabetes mellitus) and is associated with impaired endothelium-dependent relaxation as a consequence of decreased endotheliumdependent vasodilator (mainly NO) availability or increased oxidative free radical and vasoconstrictor formation [1]. Endothelial dysfunction can be evaluated by measuring flow mediated dilation (FMD) of the brachial artery by ultrasound [56]. Patients suffering from 
different cardiovascular diseases may develop a decrease in FMD, therefore changed FMD is strongly predictive of future cardiovascular events [57]. There is a high incidence of cardiovascular disease (CVD) in men with ED, and data suggest that ED may be an early manifestation of endothelial dysfunction. Thus, ED may be considered as the clinical manifestation of a disease affecting penile circulation as a part of a more generalized vascular disorder $[58-60]$.

From pharmacological point of view, it is important to mention that many drugs, used in the treatment of different disorders, has negative impact on erectile function. Centrally acting medications, like antidepressants, antipsychotics, centrally acting antihypertensive drugs, are able to alter central neurotransmitter pathways, including serotonergic, noradrenergic, and dopaminergic pathways involved in sexual function. Peripherally acting drugs, like antihypertensives, anticholinergics, may cause erectile dysfunction by potentiating the antierectile $\alpha_{1}$-adrenergic activity in the penis. Recreational drugs, like alcohol, cocaine and amphetamine derivatives, may induce erectile dysfunction via various mechanisms $[54,61]$.

\subsection{Aims of the present study}

Erection is a hemodynamic event where vasodilatation of penile arteries is followed by increased arterial blood inflow to the corpora cavernosa. In this process endothelium is an important contributor, since it plays a key role in the regulation of vascular tone via synthesis / secretion of vasorelaxant mediators, like NO and prostanoids, and it is involved in the endothelium derived hyperpolarization (EDH) - type relaxation. It is accepted that there is a correlation between endothelial and erectile dysfunction. In the present thesis we were investigated the mechanisms involved in the endothelium dependent relaxation.

Our studies were focused on the following:

1. Improve surgical technique of male-to female transsexual surgery required to obtain human penis with intact vasculature for in vitro experiments.

2. In vivo investigation of flow mediated dilation in patients suffering from erectile dysfunction. 
3. In vitro investigation of endothelium-dependent vasorelaxation in human isolated intracavernous arteries.

4. In vitro investigation of the role of C-type natriuretic peptide in penile vascular relaxation.

5. In vitro investigation of $\mathrm{BK}_{\mathrm{Ca}}$ channels in endothelium-dependent and -independent relaxation of penile arteries.

\section{Methods}

\subsection{Indirect clinical investigation of human penile arteries}

\subsubsection{MEASUREMENT OF FLOW-MEDIATED DILATION}

\subsubsection{Patients}

Correlation between common risk factors of ED and cardiologic diseases was examined on 51 patients suffering from ED, with the lack of cardiac symptoms at the University of Szeged in the Urological and Internal Department between 01.01. 2006 - 31.12. 2007. Patients were selected randomly and their average age is 51,3 years.

The patients suffering from ED for six months were divided based on International index of erectile function-5 (IIEF-5) into the following groups: under 10 scores into severe one, 11-15 into moderate one, 16-20 mild one. Due to the low number of cases only two groups were used: a severe group, and the second group from the moderate and mild ones.

After that a detailed anamnesis was made, extended with the function of partnership. We were striving for excluding psychogenic ED patients. Systematic diseases, pelvic and genital previous surgeries and traumas and medications were asked. Besides a general physical examination and following an observation of secondary genital characteristic, testicles, penis and rectal digital examinations were made.

After measuring BMI, blood pressure, ECG, exercise ECG and heart US were made. The following rates were measured from blood: Htc, Hgb, liver and kidney functions, ions, LDL, HDL, triglyceride, Hgb A1C\%, testosterone, prolactin, LH, FSH.

To exclude or identify vascular origin of the ED flow mediated vasodilation /FMD/ technique was applied. During the technique the condition of endothelium of artery brachialis was examined which is a similar vessel to intracavernosus artery so its condition is well represented. 
Endothel function was validated with coronarography, PET examination, plethysmography and arteria brachialis ultrasound was applied by us.

\subsubsection{Experimental procedure}

Diameter of arteria brachialis was measured with the patient relaxing for 10 minutes /picture/. The examination is considered to be informative between 3-6 mm brachial diameter. The cuff of the blood pressure set was blown by $250 \mathrm{Hgmm}$, brachial diameter was measured after release mode. /picture/. It was shown that the highest vasodilatation happened in the first two minutes /diagram 1/ always that rate was measured. Endothelium was intact if FMD rate was $10 \%$ or above, or damaged if it was under $10 \%$. No further groups were created due to the small number of cases, although a $5-10 \%$ is considered to be a threshold limit. 200microgramm sublingual nitrate was given for control, of which effect was checked with several measures in two minutes /Fig. / Reperfusion following ischaemia and NO from endothelium cells causes vasodilatation. If endothelium is damaged, vasodilatation will be smaller.

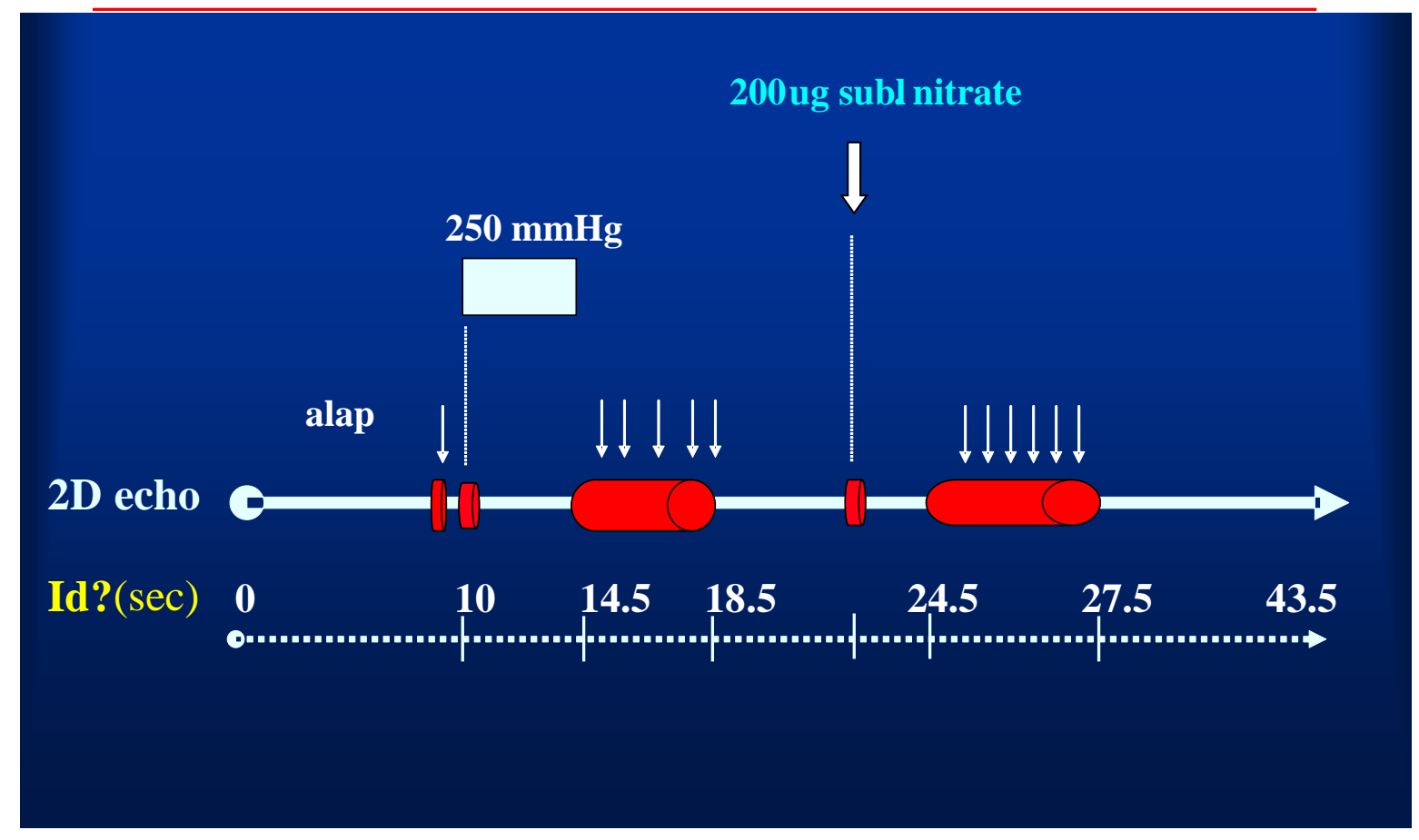

Figure 1: The protocol of the experimental procedure 


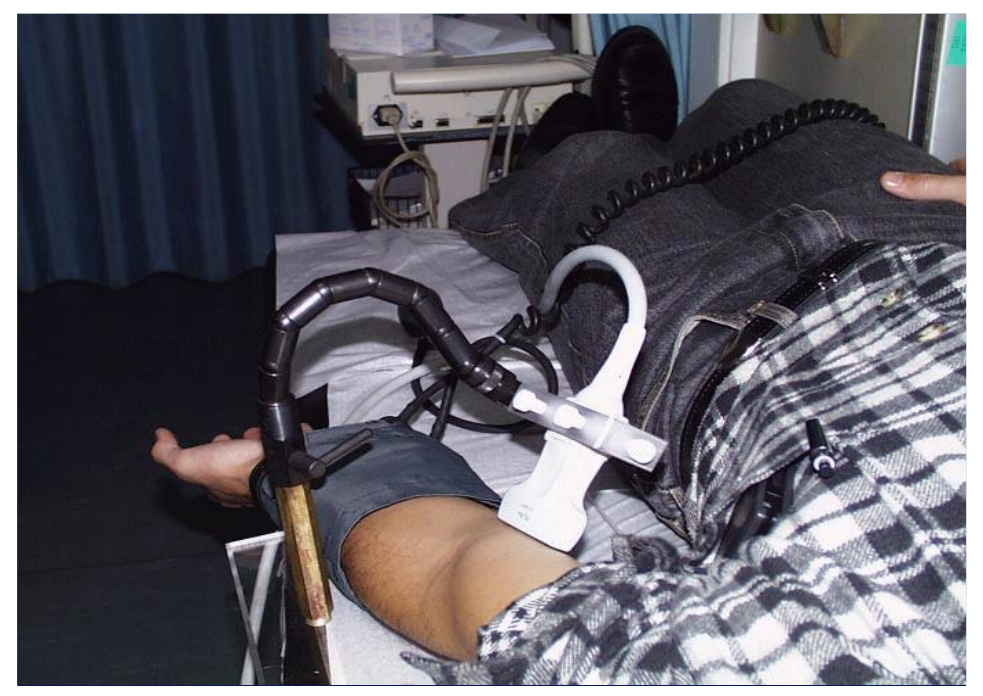

Figure 2: The measuring of the brachial artery diameter
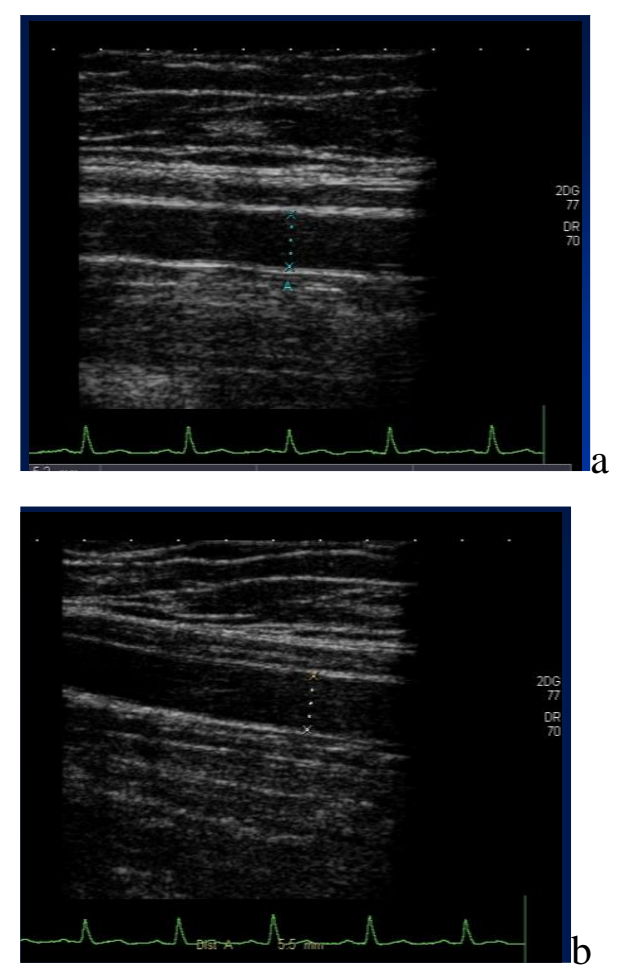


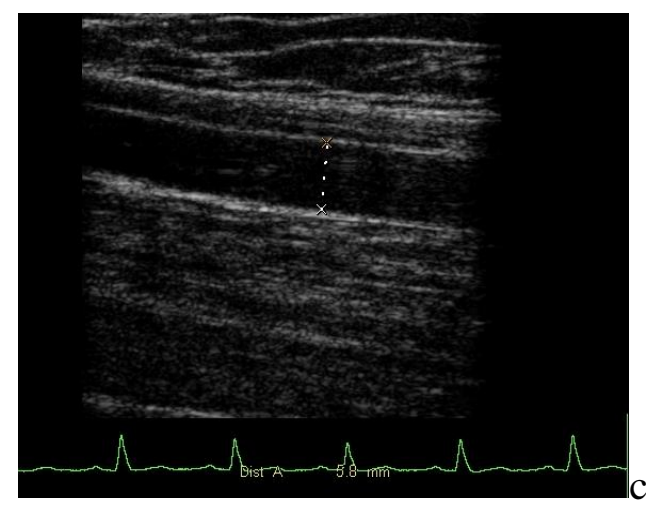

Figure 3: Relaxed brachialis can be observed in the upper US picture, in the middle the same brachialis can be seen after reperfusion, following NI giving down in the bottom and the increase of the brachialis diameter can be observed.

\subsection{Measurement of isometric tension in human intracavernous arteries}

\subsubsection{Tissue preparation and mounting}

Penile erectile tissue was obtained in connection with transsexual operations. The penis was excised and submerged immediately in ice-cold $\left(4^{\circ} \mathrm{C}\right)$ physiological salt solution (PSS). The penile artery was carefully dissected and cleaned from the adherent connective tissue. Ring segments (ca. $2 \mathrm{~mm}$ long) were mounted on two $40-\mu \mathrm{m}$ wires of isometric double myograph (Danish Myotechnology, Aarhus, Denmark). One wire was fixed to a force-transducer, the other to a length displacement device (Mulvany \& Halpern 1977; Fig. 2). Before starting the experiment, preparations were allowed to equilibrate in PSS solution, at $37^{\circ} \mathrm{C}$ and $\mathrm{pH} 7.4$, for $30 \mathrm{~min}$.

The relation between resting wall tension and internal circumference of the vessels was determined, and the internal circumference, $\quad \mathrm{L}_{100}$, corresponding to a transmural

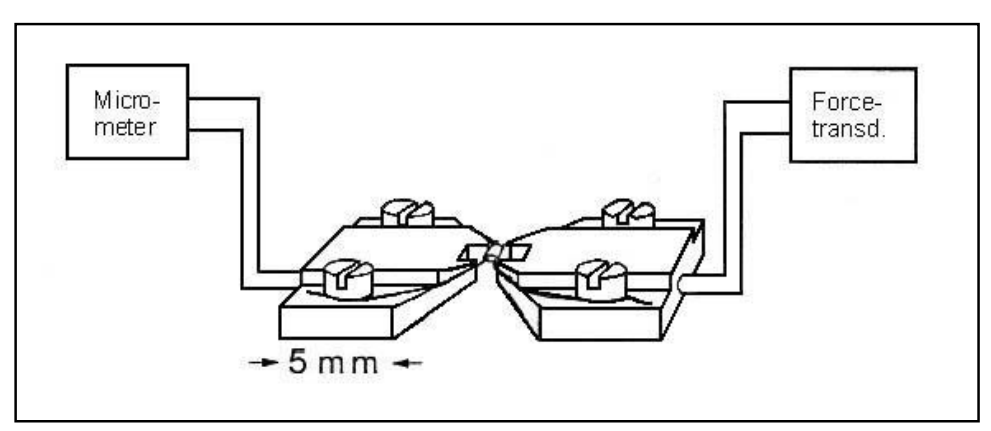

Figure 4. Schematic figure of myograph pressure of $100 \mathrm{mmHg}$ in a relaxed vessel was calculated [2]. Subsequently, the internal circumference of the vessels were set to $L_{1}$, where $L_{1}=0.9 \times L_{100}$. The effective internal lumen diameter was determined as $\mathrm{l}_{1}=\mathrm{L}_{1} / \pi$. 


\subsubsection{Experimental procedure}

To test contractility of the preparations, they were exposed twice to phenylephrine (PE, 10 $\mu \mathrm{M})$. The presence of intact endothelium was evaluated by inducing a stable contraction with phenylephrine $(10 \mu \mathrm{M})$ followed by addition of acetylcholine $(10 \mu \mathrm{M})$. Relaxation greater than $50 \%$ was taken as evidence of endothelial integrity.

Arteries were incubated with $\mathrm{N}^{\mathrm{G}}$-nitro-L-arginine methyl ester (L-NAME, $\left.300 \mu \mathrm{M}\right)$ and indomethacin $(10 \mu \mathrm{M})$ for 20 min before being contracted with phenylephrine $(3 \mu \mathrm{M})$ and cumulative concentration-response curves were constructed for the endothelium-dependent vasodilator acetylcholine ( $\mathrm{ACh}, 1 \mathrm{nM}-10 \mu \mathrm{M}$ ), the endothelium-independent vasodilator NOdonor sodium nitroprusside (SNP, $1 \mathrm{nM}-10 \mu \mathrm{M})$, CNP (0.01-1 mM) and cANF4-23 (0.01-1 $\mathrm{mM})$. the $\mathrm{BK}_{\mathrm{Ca}}$ channel activator $\mathrm{NS} 11021(0,1 \mu \mathrm{M}-100 \mu \mathrm{M})$ and for the biologically inactive analogue of NS11021, NS13558 $(0,1 \mu \mathrm{M}-100 \mu \mathrm{M})$. When the effects of inhibition of $\mathrm{K}+$ channels or Na+-K+-ATPase were tested on vasodilations, the arteries were subsequently incubated for 20 minutes with either the combination of charybdotoxin $(0.1$ $\mathrm{mM})$ plus apamin $(0.5 \mathrm{mM})$, barium $\left(\mathrm{Ba}^{2+}, 30 \mathrm{mM}\right)$ plus ouabain $(5 \mathrm{mM})$, charybdotoxin $(0.1$ $\mathrm{mM})$, or iberiotoxin $(0.1 \mathrm{mM})$, and a second concentration-response curve was obtained for the agonist.

\subsection{ETHICS}

\subsubsection{Transsexual operations}

Patients are operated with the permission of the Ministry of Health Care in the possession of a psychological, endocrinological and urological medical report submitted and approved by the Ministry of Health Care. They have personal the proper personal documents of the would be new sex. The Law says that $90 \%$ of surgical costs are paid by the transsexual person.

\subsubsection{Investigations of flow-mediated dilation}

Patients undergo the examination after detailed information of the Consent Declaration approved by the University of Szeged, Department II of Internal Medicine. 


\subsection{Analyses}

\subsubsection{Analyses of flow mediated dilations}

Statistical analyses was made with SPPSS 15.a and SigmaSat software. The FMD correlation was examined by different risk factors and linear correlation regression analyses, its dependence on smoking was tested with two sample-t.

\subsubsection{Analysis of isometric tension measurements}

The mechanical responses of the vessels were measured as force and were expressed as active wall tension, $\Delta T$, which is the increase in measured force, $\Delta F$, divided by twice the segment length [32]. The effects of different blockers on basal tension were expressed as percentage of phenylephrine contractions. The magnitude of relaxant responses was given as percentage of the contraction level just prior to the addition of the drug. The results were expressed as means \pm standard error of the mean (SEM), and the concentration-response curves were presented on a semilogarithmic scale. $\mathrm{N}$ represents the number of experiments, one artery per protocol per patient. Differences in concentration-response relationships between treatments were analyzed using two-way analysis of variance. Probability levels under 5\% were considered as significant.

\subsection{Drugs and other agents}

The composition of PSS was as follows (in $\mathrm{mM}$ ): $\mathrm{NaCl} 120.0 ; \mathrm{NaHCO}_{3} 20.0 ; \mathrm{KCl} 4.1$; $\mathrm{KH}_{2} \mathrm{PO}_{4}$ 1.2; $\mathrm{MgCl}_{2}$ 1.2; $\mathrm{CaCl}_{2}$ 1.5; and glucose 11.0 (pH 7.4) (REANAL, Szeged, Hungary). The following drugs were used: acetylcholine hydrochloride, apamin, barium chloride dihydrate, CNP, charybdotoxin, iberiotoxin, indomethacin, $\mathrm{N}^{\mathrm{G}}$-nitro-L-arginine methyl ester, ouabain, papaverine hydrochloride, phenylephrine hydrochloride and sodium nitroprusside dehydrate (Sigma, St. Louis, MO, USA). All drugs were dissolved in distilled water except indomethacin (70\% ethanol). NS11021 ((1-(3,5-bis-trifluoromethyl-phenyl)-3-[4-bromo-2(1H-tetrazol-5-yl)-phenyl]-thiourea)), NS13558 ((1-(3,5-bis-trifluoromethyl-phenyl)-3-[4bromo-2-(2-methyl-2H-tetrazol-5-yl)-phenyl]-thiourea)) were kind gifts of Joachim Demnitz, 
NeuroSearch A/S Ballerup, Denmark.. NS11021 and NS13558 were dissolved in DMSO to obtain concentrated stock solutions and then were diluted to their final concentration. The maximal DMSO $(0.1 \%)$ and ethanol $(0.07 \%)$ concentrations applied in vitro did not modulate smooth muscle tone in control experiments. All other drugs were dissolved in distilled water.

\section{RESULTS}

\subsection{MEASUREMENT OF CHANGE IN FLOW-MEDIATED DILATION IN PATIENTS SUFFERING FROM ERECTILE DYSFUNCTION}

\subsubsection{Patients characteristics}

23 patients from the 51 ones with ED were healthy and the other 28 patients considered themselves to be healthy but the examinations showed high blood pressure and laboratory deviation. FMD rate was below $10 \%$ with 13 patients from the 23 'healthy' ones and in the other group 22 from the 28 ones were pathological. 4 patients had psychogenic ED from the normal FMD level ones and their average age was lower and they did not smoke .

If cases of psychogenic origin are excluded, pathological FMD was found with 35 patients from $47 \mathrm{ED}$ ones, and that means a high $76 \%$ rate.

\subsubsection{Effect of age and smoking on flow-mediated dilation}

A negative correlation between FMD and smoking, FMD and age. Significance level between FMD and age is $(\mathrm{p}=0,001)$

Following the exclusion of ED patients of psychological origin, 20 patients from the 32 mild moderate ED ones had pathological FMD level (62\%) while 14 patients from the 15 severe ED ones had pathological FMD (93\%). Although the difference is striking if FMD rates are coordinated to IIEF scores, no linear correlation can be determined. 

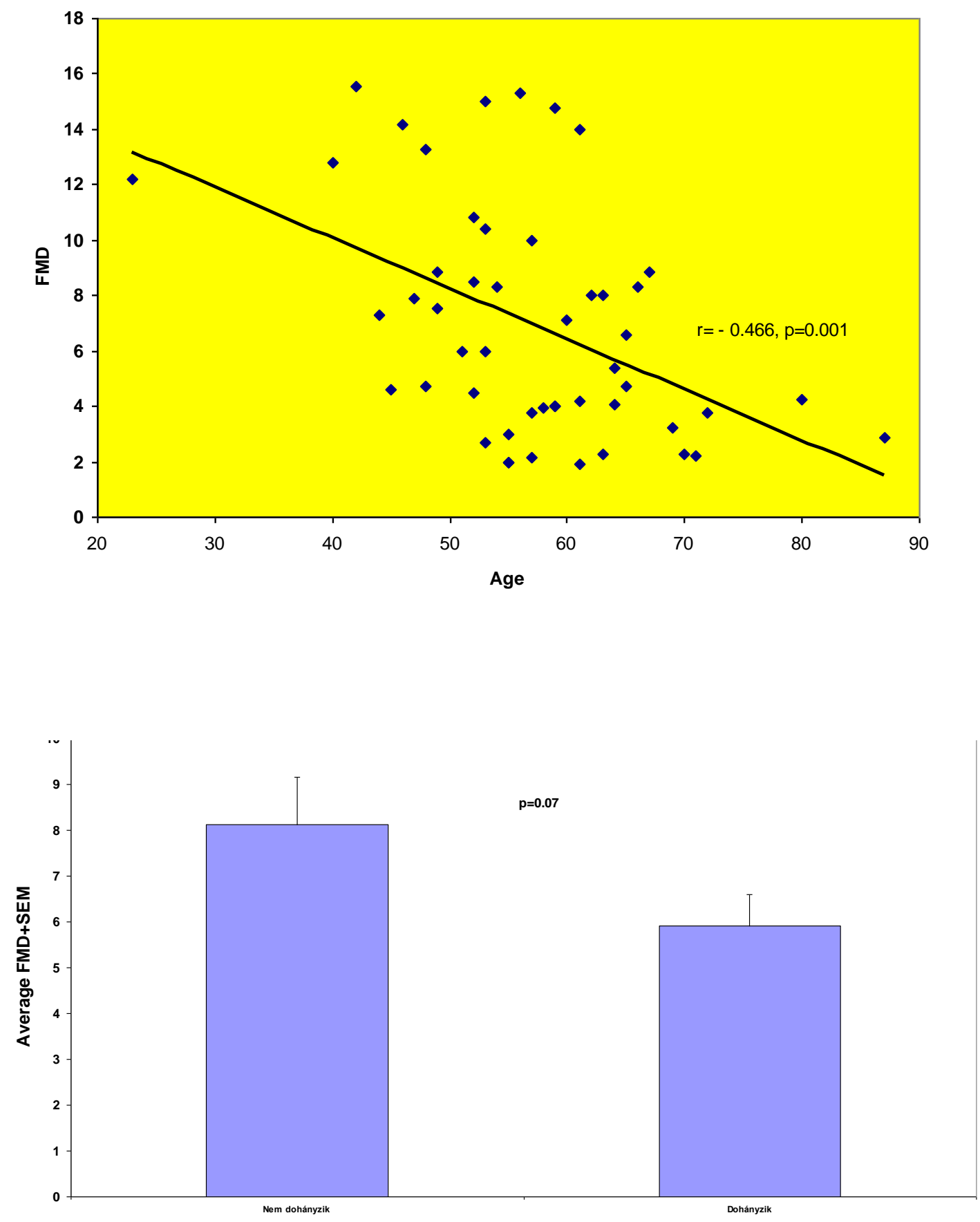

Figure 5. A negative correlation between age and FMD and smoking and FMD 
3.1.3. Effect of body-mass index, cholesterol and triglyceride level on flow-mediated dilation

Due to high scattering no correlation was found between BMI and FMD scores. No correlation could be shown between FMD and triglyceride level either and between FMD and cholesterol. It can be explained that only one blood sample was made and the increased rate of blood lipids and the existence period of their pathological rate was not examined. We assume that the high blood lipid level existing for decades causes endothelium dysfunction.

BMI and FMD
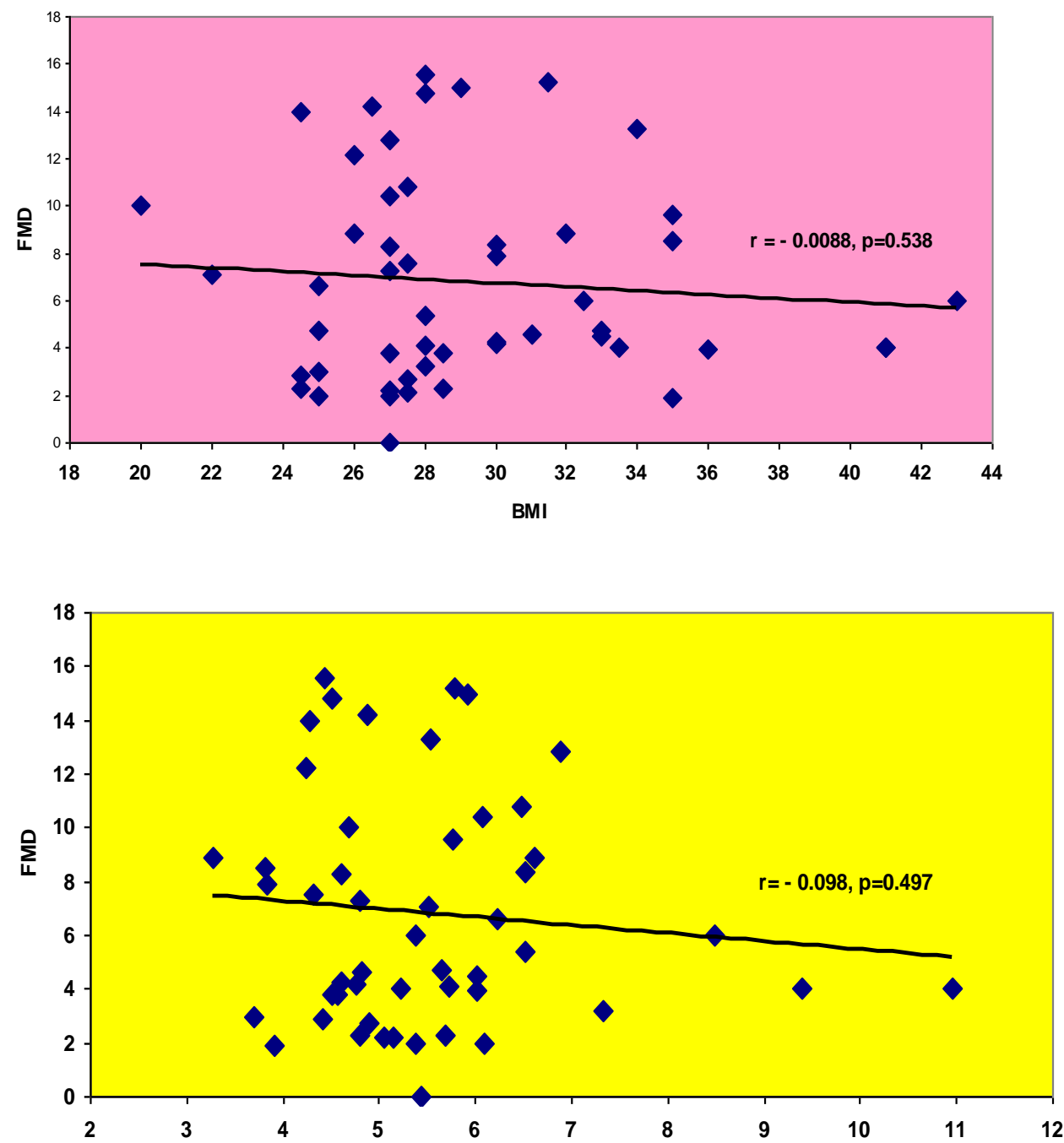

Cholesterol 


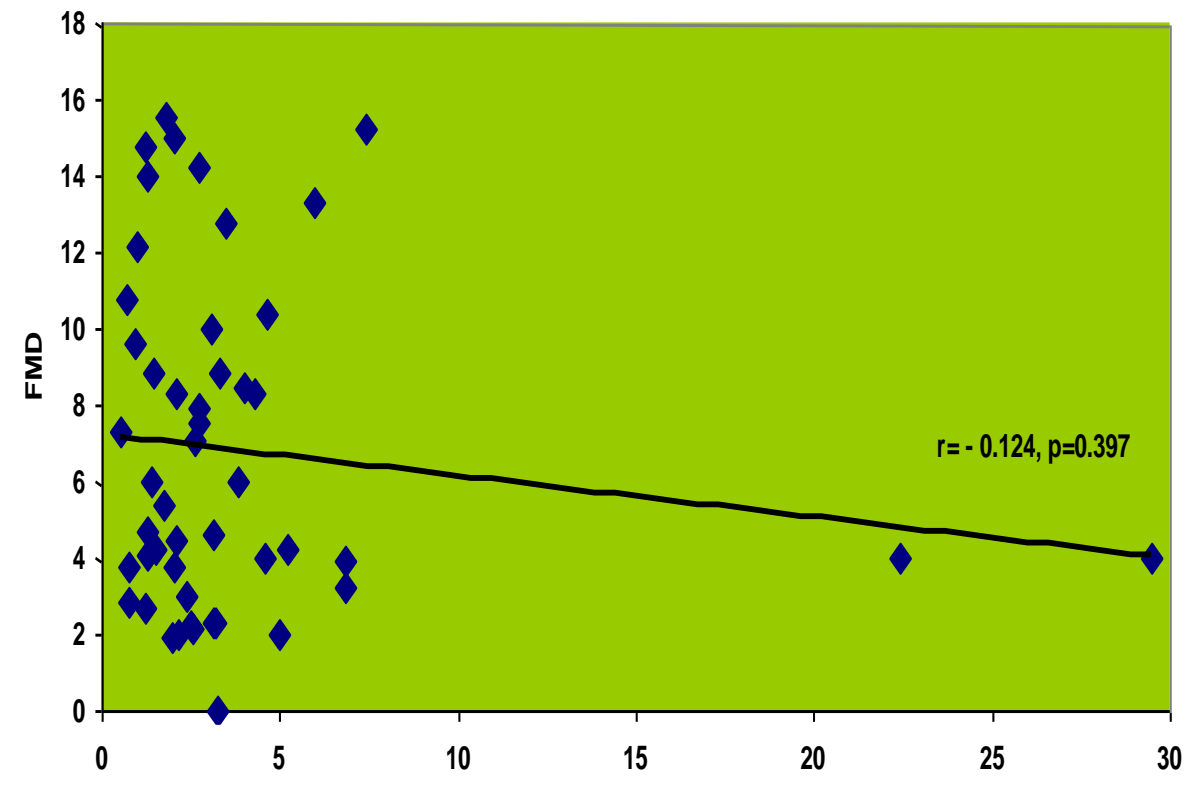

Triglyceride

Figure 6.: No correlation between BMI either and between FMD and cholesterol, and FMD and triglyceride level

\subsection{INVESTIGATION OF ENDOTHELIUM-DEPENDENT RELAXATION IN HUMAN INTRACAVERNOUS ARTERIES}

Human penile small arteries with normalized internal lumen diameter of $557 \pm 20 \mathrm{~mm}$ were contracted with phenylephrine $(10 \mu \mathrm{M})(\mathrm{n}=74$ arteries from 21 patients). Average contraction was $6.5 \pm 0.2 \mathrm{~N} / \mathrm{m}(\mathrm{n}=74)$.

\subsubsection{Determination of the role of EDHF in ACh-evoked relaxation}

In penile arteries contracted with phenylephrine $(3 \mu \mathrm{M})$, ACh $(1 \mathrm{nM}-10 \mu \mathrm{M})$ evoked concentration-dependent relaxation in endothelium-intact but not in endothelium-denuded segments with maximal relaxation and $\mathrm{pD}_{2}$ value of $87.1 \pm 2.6 \%$ and $7.5 \pm 0.2(\mathrm{n}=14)$, respectively. Incubation with an inhibitor of NO synthase, L-NOARG (100 mM), and cyclooxygenase, indomethacin $(10 \mu \mathrm{M})$, significantly reduced the ACh relaxation (Figure 7). The $\mathrm{pD}_{2}$ value for $\mathrm{ACh}$ in the presence of $\mathrm{L}-\mathrm{NOARG}+$ indomethacin was $6.8 \pm 0.1(\mathrm{n}=14)$. 


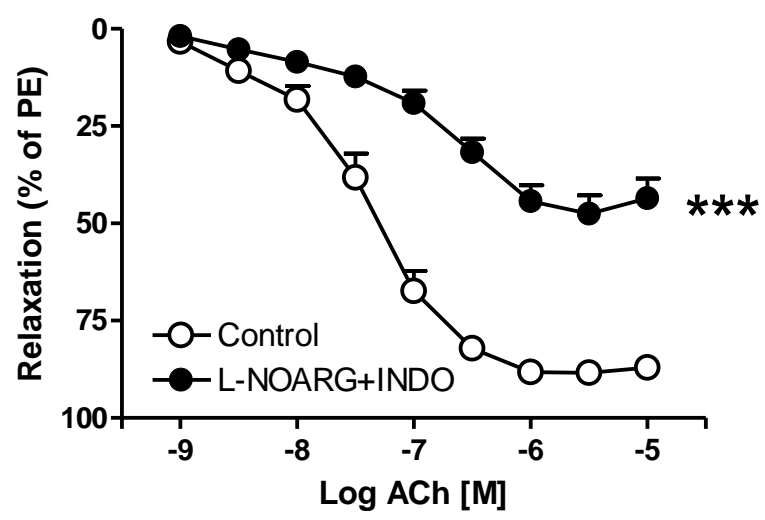

Figure 7. Concentration-response curves for ACh in the absence (control) and presence of NG-nitro-L-arginine (LNOARG), and indomethacin (INDO), inhibitors of nitric oxide synthase and cyclooxygenase, respectively. $* * * \mathrm{p}<0.001$ by two-way ANOVA.

\subsubsection{Effect of blockers of the EDHF pathway on ACh relaxation}

In the presence of L-NOARG and indomethacin, the residual ACh relaxation was inhibited by treating the arteries with charybdotoxin (ChTX, $0.1 \mu \mathrm{M}$ ), a blocker of intermediate-conductance $\mathrm{Ca}^{2+}$-activated $\mathrm{K}^{+}$-channel (Control: $61.2 \pm 5.8 \%$ vs ChTX: $33.2 \pm$ $6.1 \%, \mathrm{n}=5$, Figure 8). Combination of charybdotoxin and apamin, blockers of intermediateand small-conductance $\mathrm{Ca}^{2+}$-activated $\mathrm{K}^{+}$-channels, respectively, abolished the ACh-induced vasodilation (Control: $55.1 \pm 9.0 \%$ vs $\operatorname{ChTX}(0.1 \mu \mathrm{M})+$ Apamin $(0.5 \mu \mathrm{M}): 14.6 \pm 2.5 \%, \mathrm{n}=$ 5, Figure 8).

\section{a}

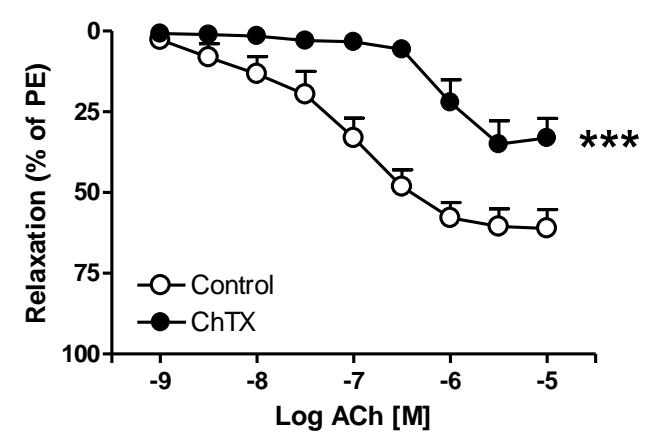

b

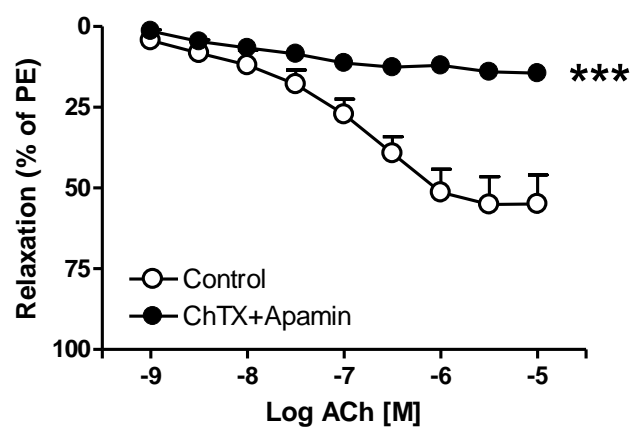

Figure 8. Concentration-response curves for $\mathrm{ACh}$ in the absence (control) and presence of (a) charybdotoxin (ChTX) and (b) charybdotoxin plus apamin. $* * * p<0.001$ by two-way ANOVA. 


\subsubsection{Effect of IbTX on ACh relaxation}

To investigate the role of $\mathrm{BK}_{\mathrm{Ca}}$ channels in endothelium-dependent and -independent relaxation, iberiotoxin (IbTX, $0.1 \mu \mathrm{M}$ ), a selective blocker of $\mathrm{BK}_{\mathrm{Ca}}$ channels, was used. Iberiotoxin inhibited the endothelium-dependent, acetylcholine-evoked vasodilatations both in the absence (control: $89.9 \pm 1.7 \%$ vs IbTX: $53.0 \pm 9.4 \%, \mathrm{n}=7, \mathrm{p}<0.001$, Figure 9) and presence of L-NAME plus indomethacin (L-NAME+INDO: $35.5 \pm 4.1 \%$ vs. L-NAME+INDO+IbTX: $14.8 \pm 8.6 \%, \mathrm{n}=7, \mathrm{p}<0.001$, Figure 10).

a
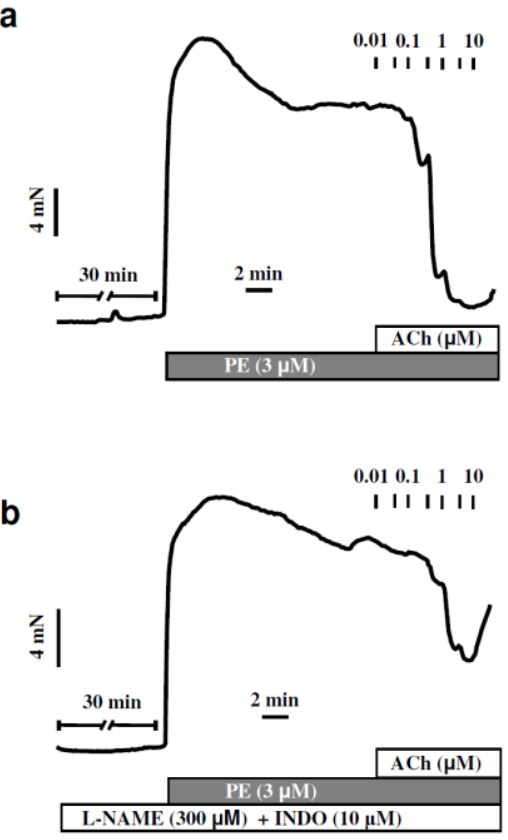

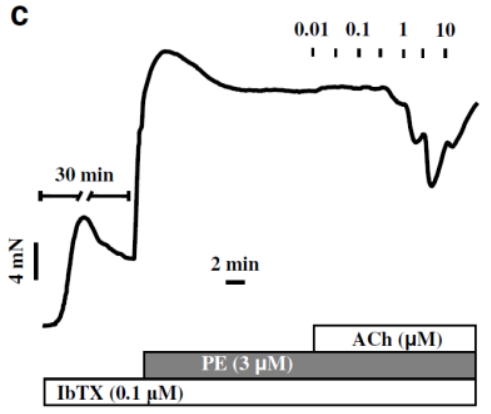

d

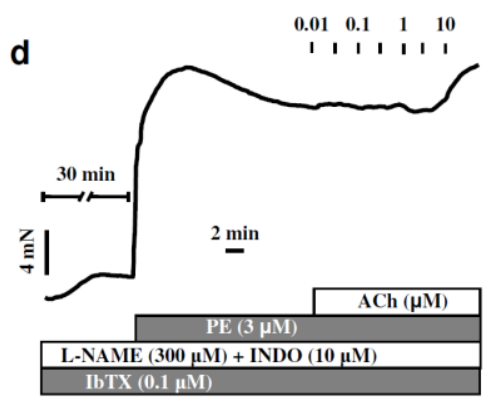

Figure 9. Original traces showing the relaxing effect of $\mathrm{ACh}$ in the absence (a, b) and presence (c, d) of iberiotoxin (IbTX). AChevoked relaxations were recorded in the absence $(\mathbf{a}, \mathbf{c})$ and presence $(\mathbf{b}, \mathbf{d})$ of L-NAME plus indomethacin. The horizontal bar indicates time, and the vertical bar

indicates increase in force $(\mathrm{mN})$.

Iberiotoxin also induced rightward shift in dose-response curve $\left(\mathrm{pD}_{2}\right.$ values for control: $7.7 \pm 0.3$ vs IbTX: $6.7 \pm 0.1, \mathrm{n}=7, \mathrm{p}<0.05 ; \mathrm{pD}_{2}$ values for L-NAME+INDO: $6.7 \pm 0.1$ vs. L-NAME+INDO+IbTX: $6.3 \pm 0.3, \mathrm{n}=7, \mathrm{p}>0.05)$.

a

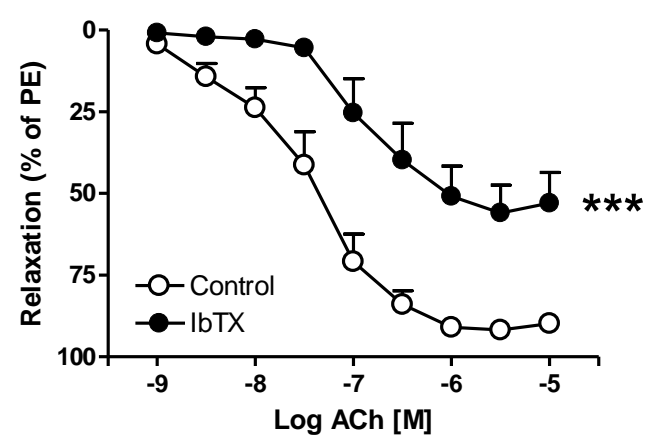

b

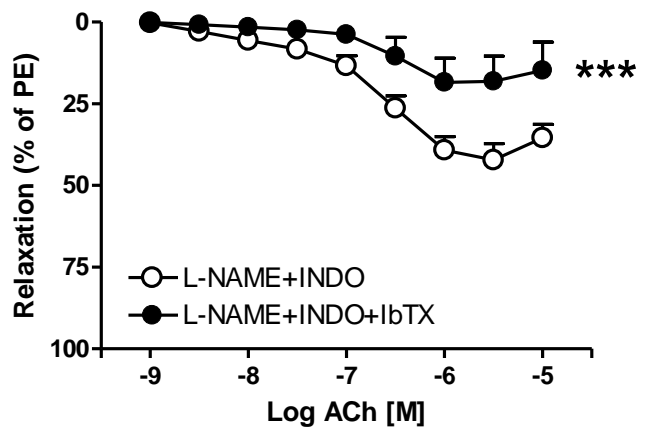


Figure 10. Concentration-response curves for ACh in the absence and presence of (a) iberiotoxin (IbTX) and (b) L-NAME plus INDO. *** p<0.001 by two-way ANOVA.

\subsection{INVESTIGATION OF ENDOTHELIUM-INDEPENDENT RELAXATION IN HUMAN INTRACAVERNOUS ARTERIES}

\subsubsection{Characterization of CNP-evoked relaxation}

In arteries with endothelium (Figure 11) and contracted with phenylephrine in the presence of L-NOARG and indomethacin, CNP (0.01-1 $\mathrm{mM})$ evoked concentrationdependent relaxations (Figures 11 and 12). The concentration-response curves for CNP were reproducible up to three times and were unaltered in preparations without endothelium. In the presence of L-NOARG and indomethacin and contracted with high extracellular $\mathrm{K}^{+}(80 \mathrm{mM})$, CNP relaxation was markedly blunted (Figures 11 and 12).

In the presence of L-NOARG and indomethacin, incubation of the arteries with charybdotoxin alone (Figure 12) or a combination of charybdotoxin plus apamin (Figure 12), markedly reduced CNP relaxation. 


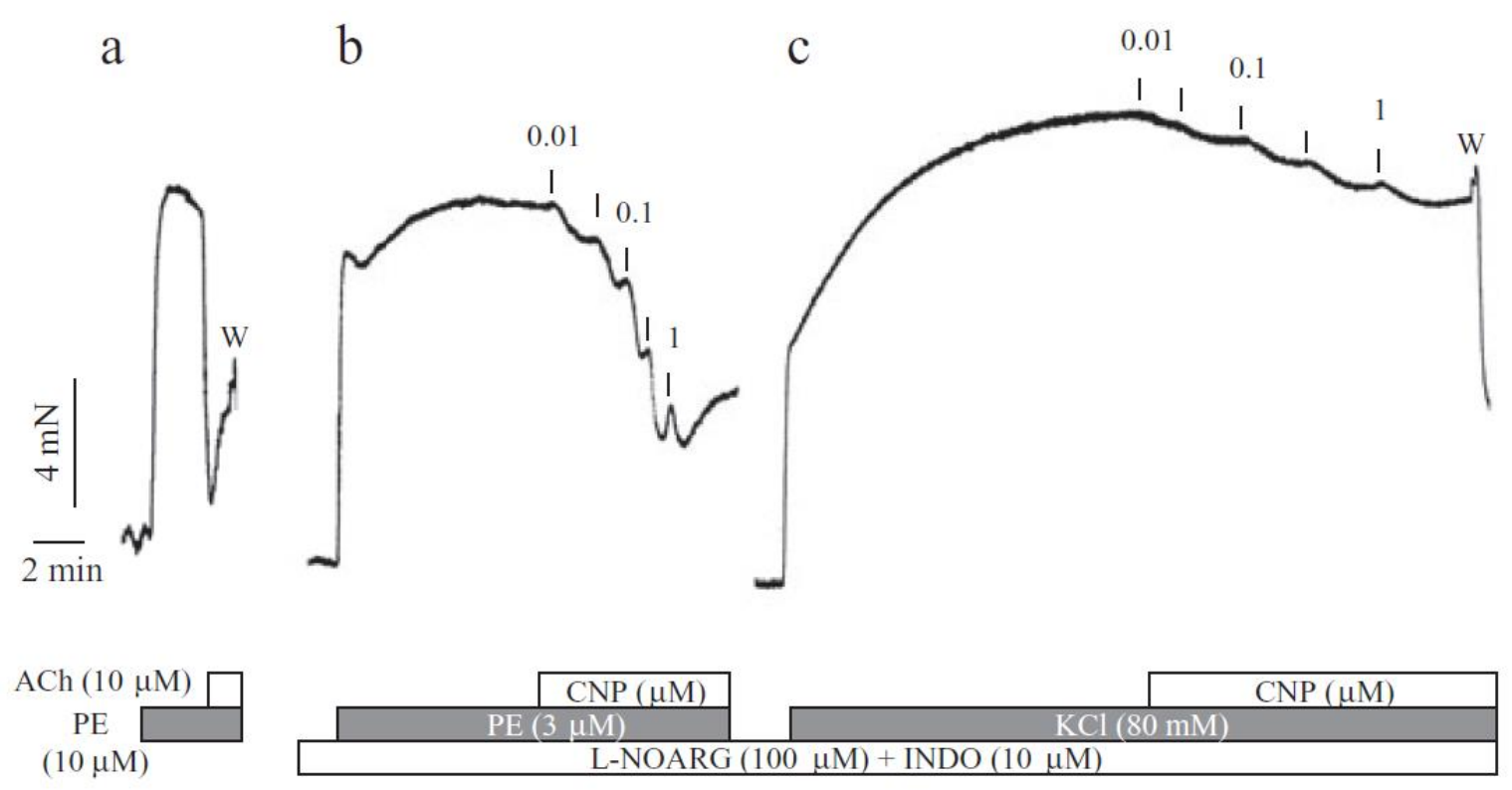

Figure11. Original traces showing the relaxing effect of C-type natriuretic peptide (CNP) in human penile small artery. (a) Contraction induced by phenylephrine (PE, $10 \mu \mathrm{M})$ followed by acetylcholine (ACh, $10 \mu \mathrm{M}$ ). (b) In the arterial segment contracted by PE, CNP induced concentration-dependent relaxation. (c) In the same arterial segment contracted with 80-mM K $\mathrm{K}^{+}$-rich physiological salt solution, CNP relaxation was markedly reduced. The horizontal bar indicates time, and the vertical bar indicates increase in force $(\mathrm{mN})$. $\mathrm{W}=$ washout.

a

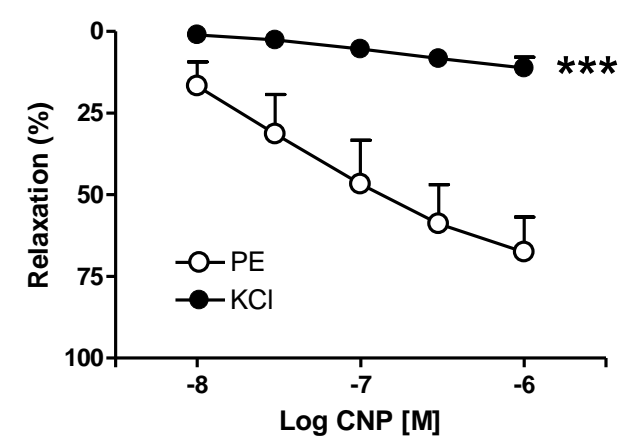

b

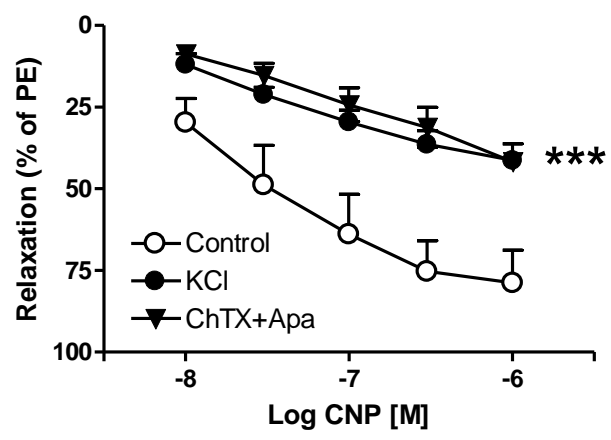

Figure 12. (a) Average concentration-response curves for CNP in preparations contracted with phenylephrine (PE) or with $80 \mathrm{mM} \mathrm{K}^{+}(\mathrm{n}=5)$. (b) Average concentrationresponse curves for CNP alone or in combination with charybdotoxin (ChTX) $(n=4)$ or 
ChTX plus apamin (ChTX + Apa) $(\mathrm{n}=4)$ in PE-contracted penile arteries. Results are means \pm standard error of the mean. $* * * \mathrm{p}<0.001$ by two-way ANOVA.

\subsubsection{Effect of IbTX on CNP-evoked relaxation}

To test whether BKCa channels were involved in CNP-evoked relaxation, the blood vessels were incubated with iberiotoxin $(0.1 \mu \mathrm{M})$. In the presence of L-NOARG and indomethacin, iberiotoxin markedly reduced the concentration-response curves for CNP (Figure 13) compared to parallel control experiments (Figure 13)
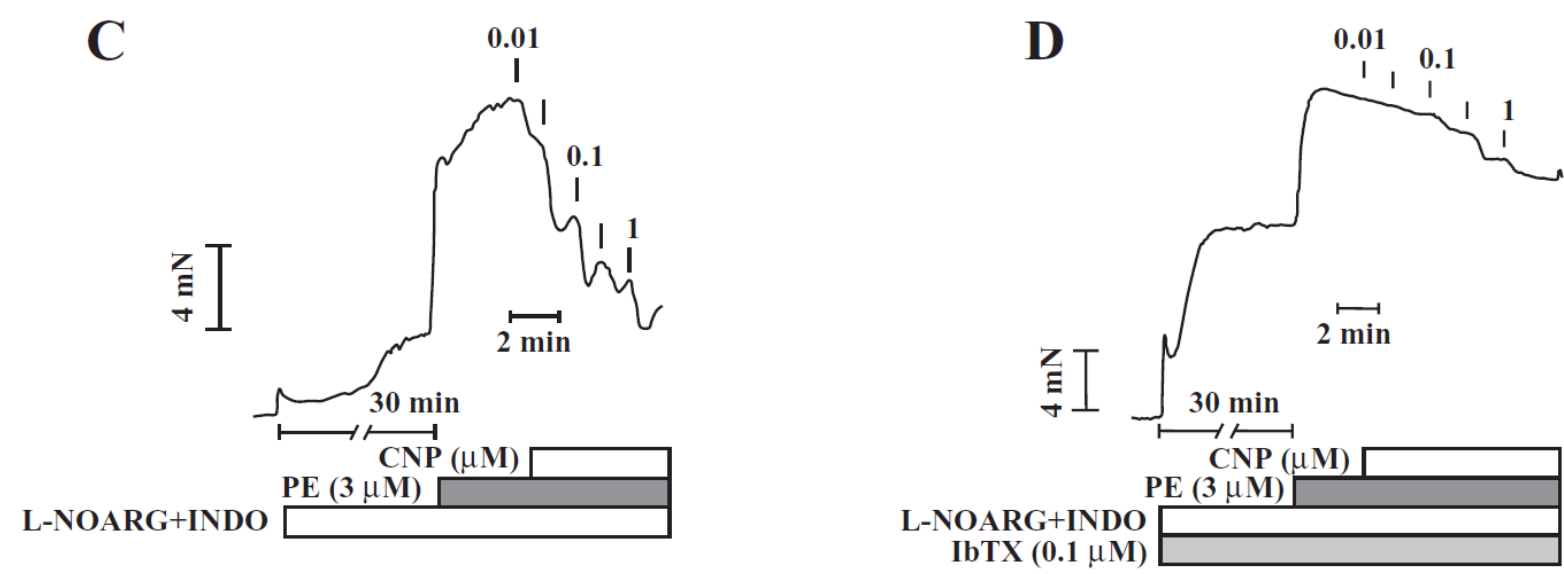

Figure 13. $\mathrm{BK}_{\mathrm{Ca}}$ channels involved in C-type natriuretic peptide (CNP)-evoked relaxation. Original traces showing the relaxing effect of CNP in human penile small arteries in the (a) absence and (b) presence of a blocker of $\mathrm{BK}_{\mathrm{Ca}}$ channels, iberiotoxin (IbTX). The traces are representative for two experiments obtained from two patients. The horizontal bar indicates time, and the vertical bar indicates increase in force $(\mathrm{mN})$.

\subsubsection{Effect of IbTX on SNP-induced relaxation}

The NO-donor, endothelium-independent vasodilator, sodium nitroprusside-induced relaxations were inhibited by iberiotoxin (Control: $88.0 \pm 8.4 \%$ vs. IbTX: $66.0 \pm 4.6 \%, n=6$, $\mathrm{p}<0.001$, Figure 14). The corresponding $\mathrm{pD}_{2}$ values for $\mathrm{SNP}$ were $7.9 \pm 0.2$ and $7.2 \pm 0.1$ in the absence and presence of IbTX, respectively $(n=6, p<0.05)$.

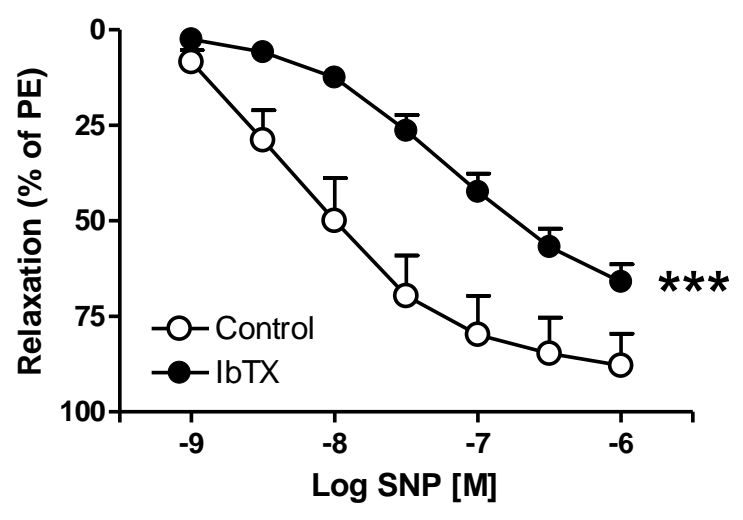


Figure 14. Concentration-response curves for SNP in the absence and presence of iberiotoxin (IbTX). *** $\mathrm{p}<0.001$ by two-way ANOVA.

\subsection{EFFECT OF NS11021, A PUTATIVE BKCA OPENER, IN HUMAN INTRACAVERNOUS ARTERIES}

NS11021, a selective opener of $\mathrm{BK}_{\mathrm{Ca}}$ channels at low concentrations, evoked powerful relaxation, which was inhibited and right-shifted in the presence of the $\mathrm{BK}_{\mathrm{Ca}}$ channel blocker iberiotoxin (Figure 15). NS11021 $\mathrm{pD}_{2}$ values were $5.8 \pm 0.1$ and $5.0 \pm 0.1$ in the absence and presence of IbTX, respectively $(\mathrm{n}=5, \mathrm{p}<0.01)$. NS13558, the biologically inactive analogue of NS11021, did not induce significant relaxation in human penile small arteries, compare to NS11021 (38.1 $\pm 5.8 \%$ vs. $95.6 \pm 2.0 \%$, respectively $n=4-5, p<0.001$, Figure 15$)$.

a

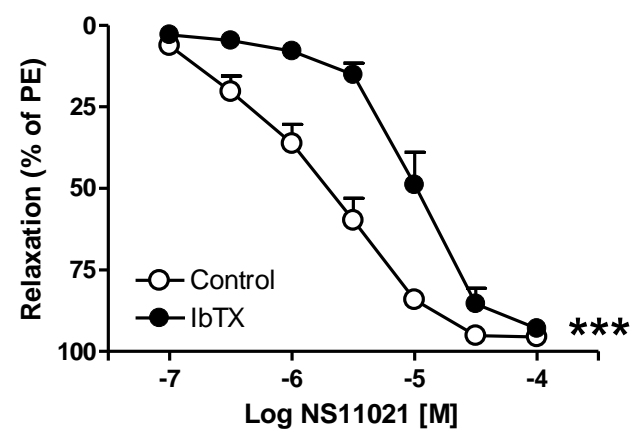

b

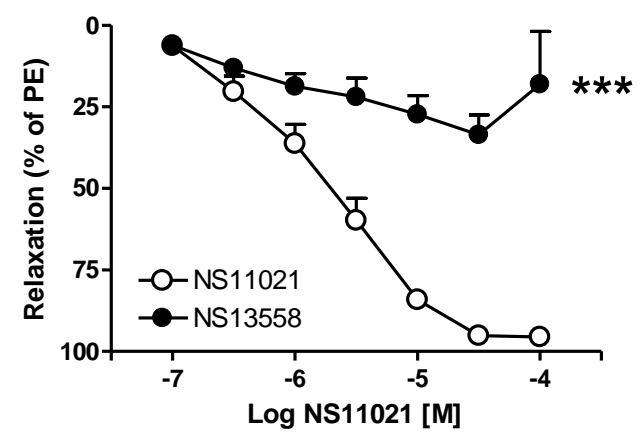

Figure 15. Concentration-response curves for NS11021, a $\mathrm{BK}_{\mathrm{Ca}}$ channel opener, (a) in the absence and presence of iberiotoxin (IbTX) and (b) comparison of NS11021 with NS13558, the biologically inactive analogue of NS11021. *** $\mathrm{p}<0.001$ by two-way ANOVA. 


\section{DISCUSSION}

\subsection{Changes in surgical technique in transsexual operation}

The examination of erection research of human penis was made possible male by female sexual reassignment surgery at the University of Szeged in the Urological Department. Transformation of sex is a multi phase operation, its essential part is creating a new female genital organ which operates both esthetically and functionally well. The current operational technique was has been developed by continuous changes based on 14 year experience.

The operation is made in a lithotomy position. The earlier turned down u-shape perineal incision, which resulted a threshold building at the neovagina, was exchanged by median sagittal incision. (Figure 16).

Degloving of penis is made after castration. When the patient does not circumcise and its individual sizes make it possible to save a part of the inner layer of the foreskin, the inner lips are created from that one. The next step is to separate the urethra from corpus cavernosum penis (Figure 17).

Division of penis into parts is continued. Saving the penile dorsal neurovascular bundle is essential to the function of newly created clitoris. The neurovascular bundle used to be separated from the corpus cavernosum along with tunica albuginea, so that the possibility of neurovascular injury was minimized. (Figure 18).

As the patients are genetically male, the pelvis of male to female of transsexual patients is tight, the neurovascular bundle separated together with tunica albuginea takes a big place, so the entry of the neovagina is critically tightening, with the increased experience we have returned to the isolation of neurovascular bundle itself because it takes a smaller place and the number of tissue lost of the newly created clitoris has not increased.

Corpus cavernosum is exstirpated from the inferior wing of symphisis. A greater part of the glans is used at the creation of clitoris, one part of it is deepithelialized and it is sank under the skin. The inner lips are created in the inner layer of foreskin left on glans and the fixing sutures of the neo clitoris is placed into foreskin to avoid circular damage (Figure 19).

After the separation of penis the preparation of the space of the neovagina is followed. The bulbar urethra is separated from the rectum the centrum tendineum is cut. When the place is 
too tight, the spongiosus tissue of bulbar urethra may be resected. The prostate is reached and partly mobilized as in the case of perineal prostatectomy. The muscle of pelvic floor is perforated and it is incised ceating a fairly wide cave for the neo vagina. The parameter of vagina is determined by the individual size of the penis. The patient expects a proper diameter neovagina. The solution of the problem was provided by the non used pendular urethra, which is separated from the neomeatus in dorsal two third, but the ventral one third of the urethra is preserved to keep blood supply and that part of the urethra is detubularised and the anterior wall of the neovagina is created from that part. (Figure 20). The result of that is the diameter growth of the vagina and the spongiosus tissue participating in vagina creation increases the pleasure of sexual intercourse. The distal part of the penile skin which is the end of neovagina closes with absorbable running sutures(Figure 21).

The next step is to fit the neovagina into its place and to appoint the place of clitoris and the meatus (Figure 22). If it is necessary, the skin of the abdomen is mobilized and occasionally the umbilicus is replaced. The clitoris and urethra are sutured in the earlier demonstrated way, then the neovagina is fixed with tissue glue. The inner lips are created from the inner layer of the foreskin and the outer lips are created from the resectioned scrotum skin. The upper part of the outer lips are approximated to each other after a transverse incision and sagittal suturing of the skin above the neoclitoris(Figure 23). Urethra catheter and perianal drain are left behind. The vagina is kept fixed with bandage filled condom. The drain and the condom are removed on the second postoperative day while the urethra catheter is removed on the seventh postoperative day. A hyperol and betadine lavage is applied daily. The operation is made LMWH protection. Antibiotic effecting on anaerob bacteria are given for two days parenterally and five more days enterally. The success of the operation is greatly influenced by the postoperative care. A Betadine soap treatment of the operative field is necessary at home. A regular vagina widening should immediately be started after wound healing which is made by the patient itself. 

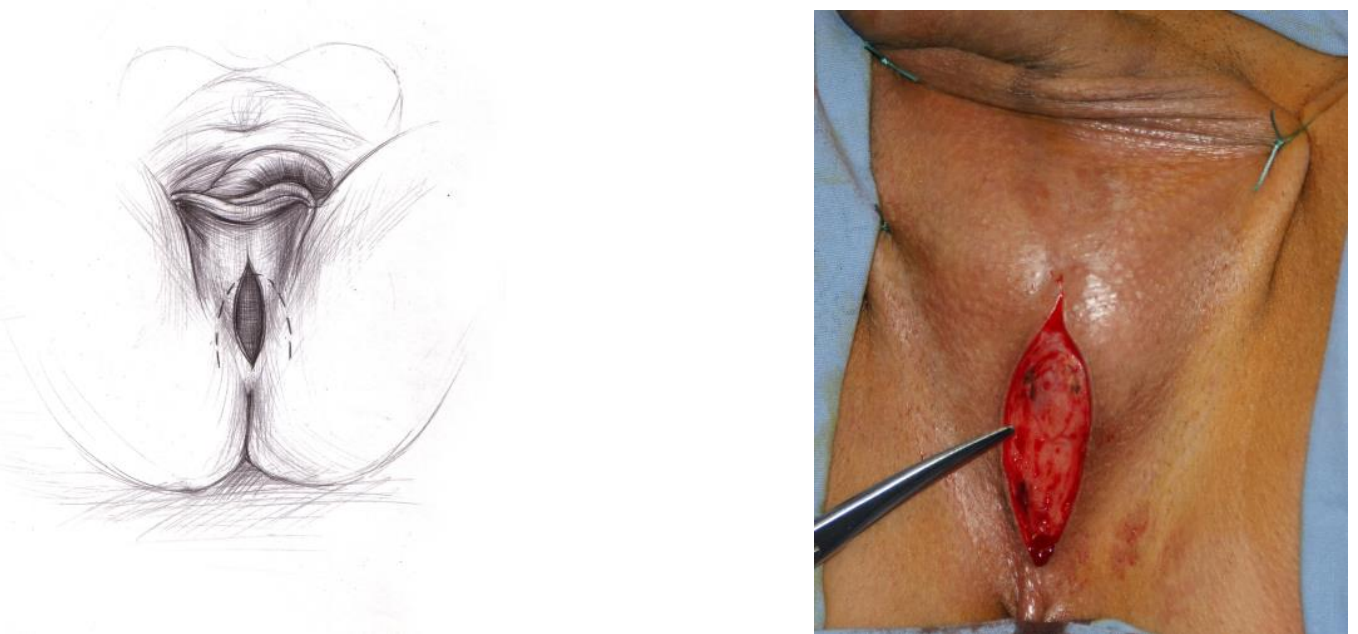

Figure 16: The earlier turned down u-shape perineal incision was exchanged by median saggital incision.

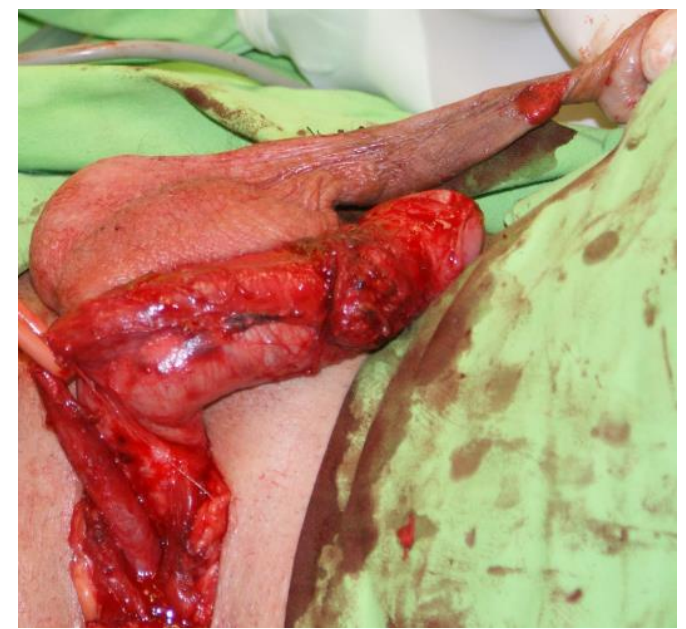

Figure 17: Separate the urethra from the corpus cavernosum 

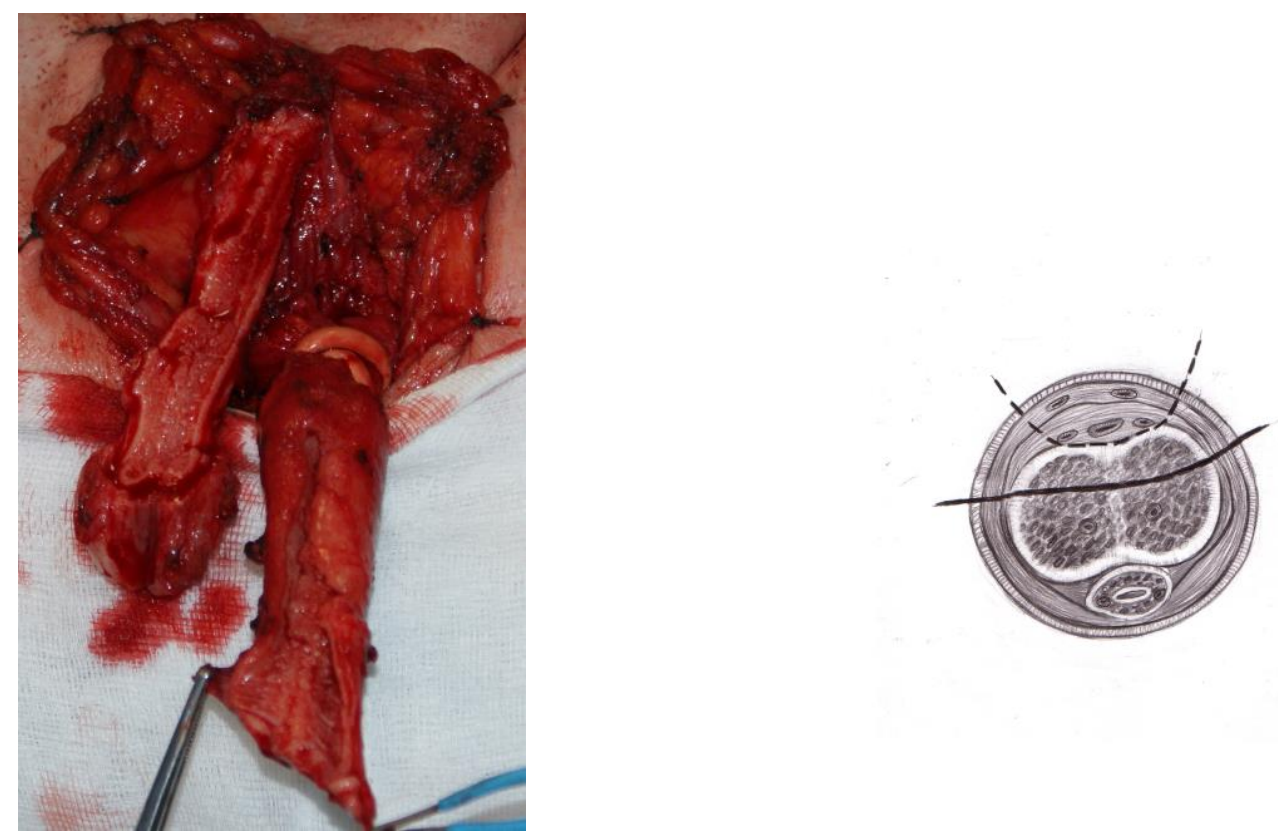

Figure 18: The neurovascular bandle used to be separated from the corpus cavernosum along with tunica albuginea
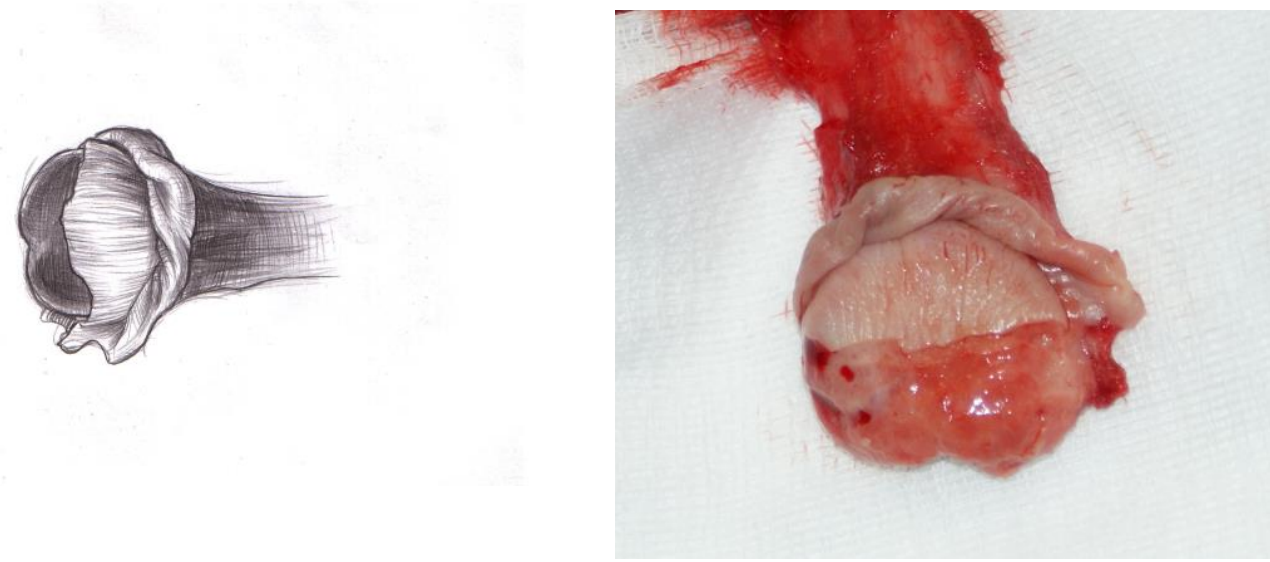

Figure 19: The greater part of the clitoris is used at the creation of the clitoris, one part of it deepithelialized and it is sank under the skin 

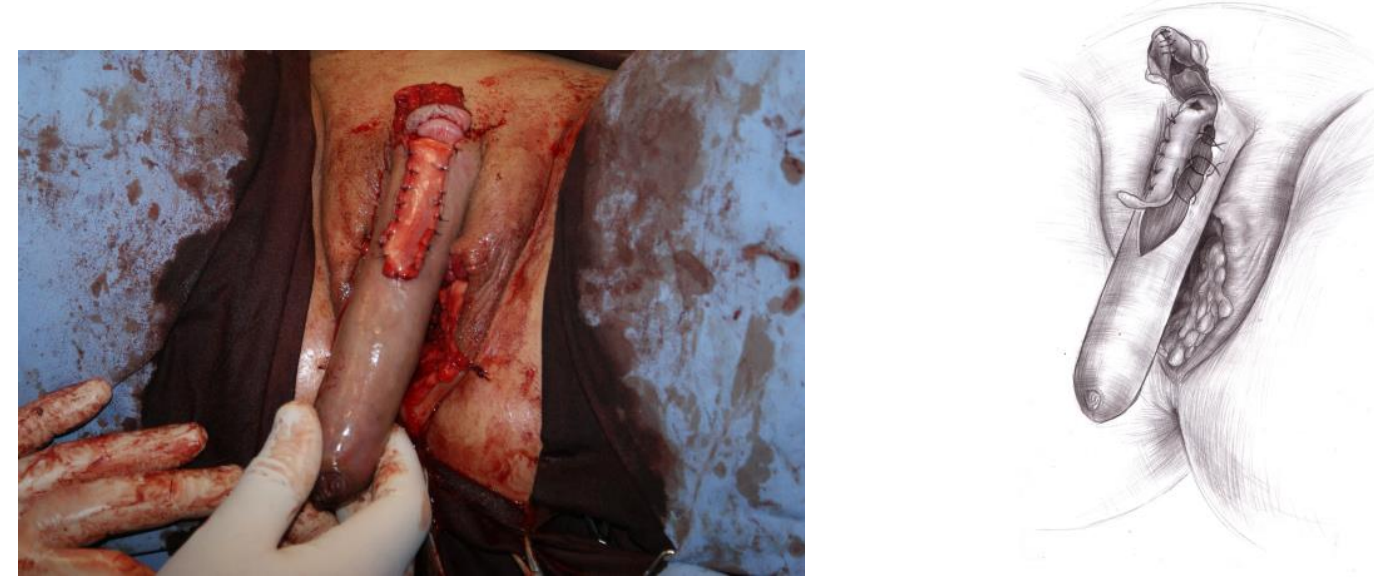

Figure 20: The pendular urethra is detubularised and the anterior wall of the vagina is created from the part

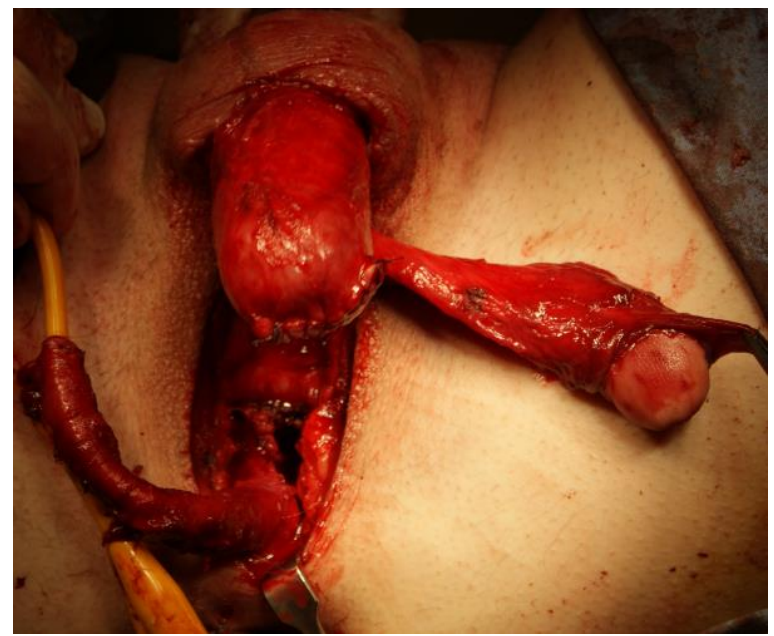

Figure 21: The neovagina is created from the penile skin. 


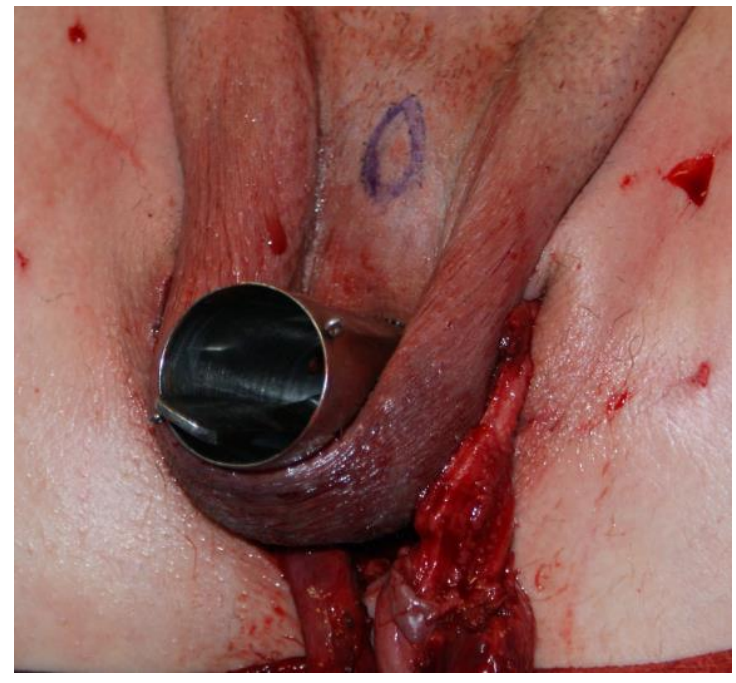

Figure 22: Fit the neovagina into its place and marking out the proper place of the meatus and clitoris.
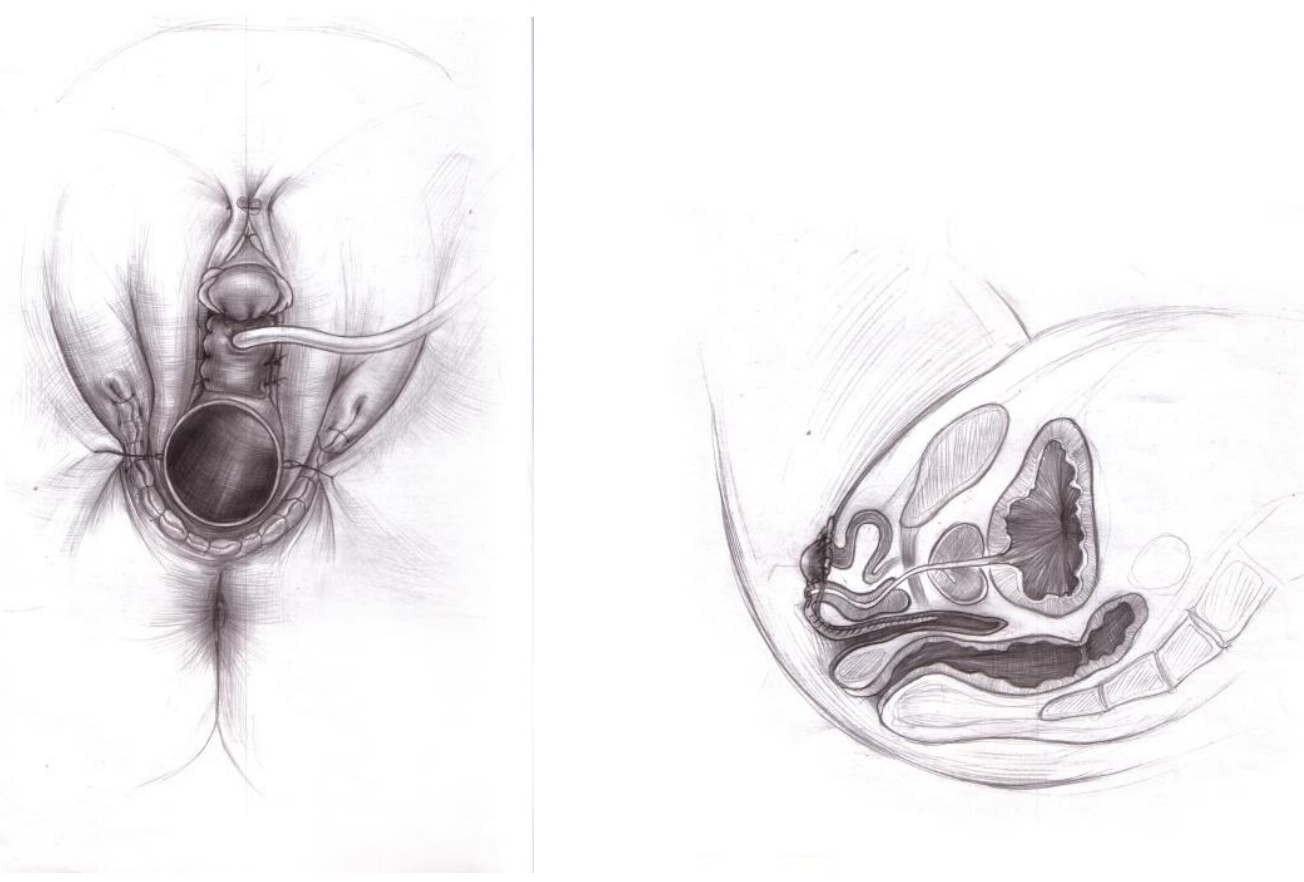


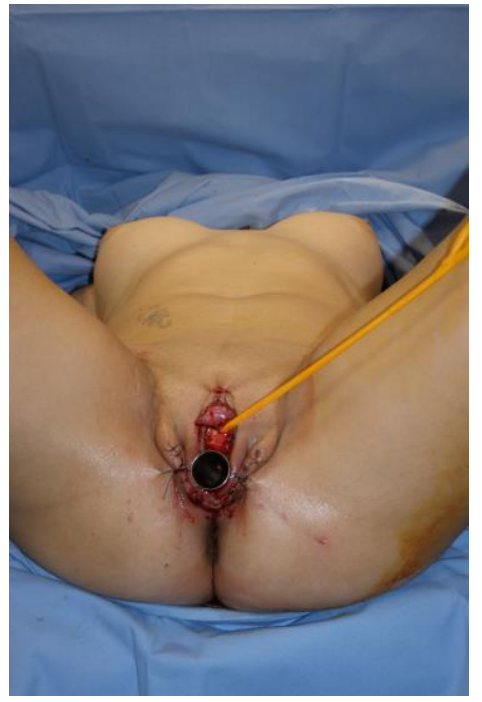

Figure 23: The outer lips are created from the resectioned scrotal skin

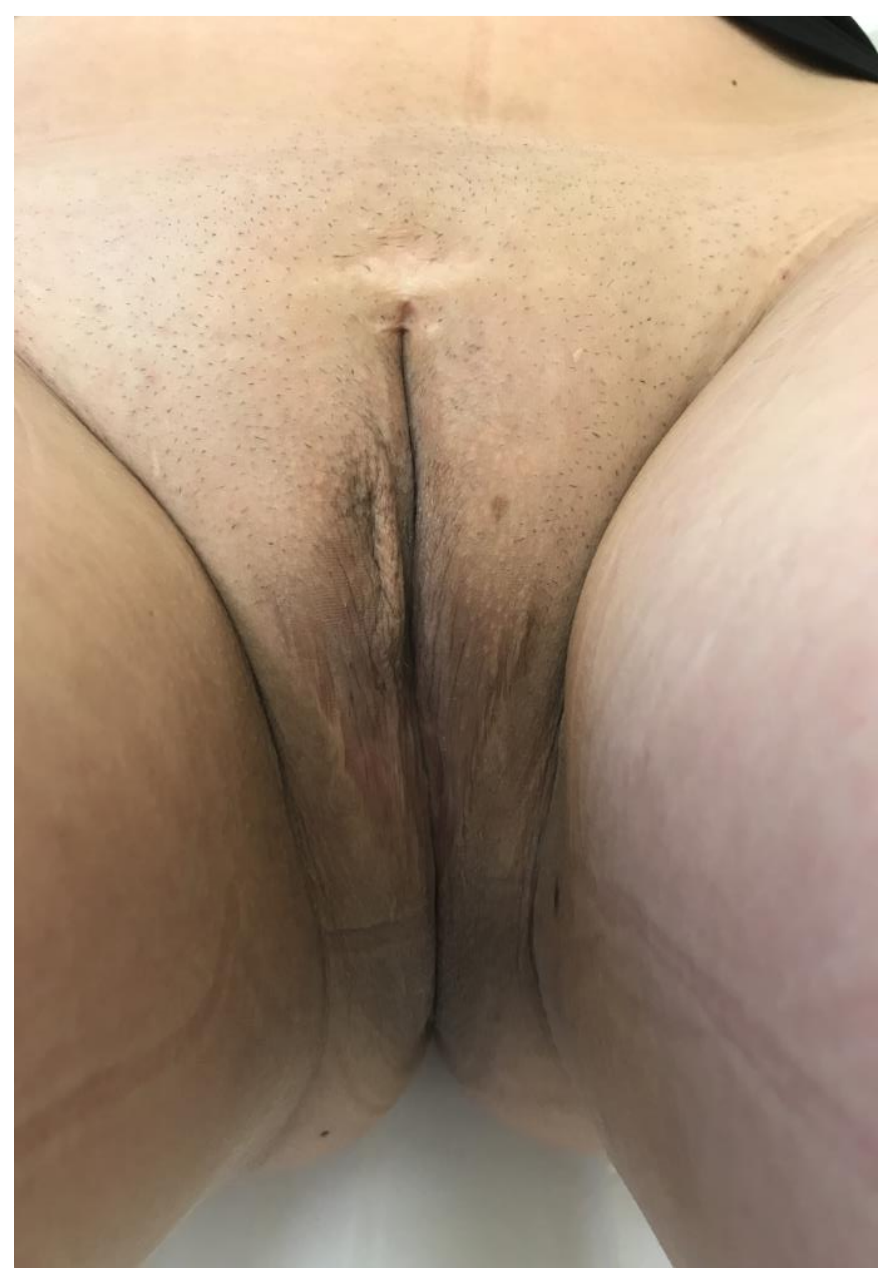

Figure 24: Six months after the operation 


\subsection{Flow-mediated dilation and erectile dysfunction}

Endothelial dysfunction is common sign in cardiovascular diseases (hypertension, atherosclerosis, smoking, and diabetes mellitus) and is associated with impaired endotheliumdependent relaxation as a consequence of decreased endothelium-dependent vasodilator (mainly NO) availability or increased oxidative free radical and vasoconstrictor formation [1]. Endothelial dysfunction can be evaluated by measuring flow mediated dilation (FMD) of the brachial artery by ultrasound [56]. There is a high incidence of cardiovascular disease (CVD) in men with ED, and patients suffering from different cardiovascular diseases may develop a decrease in FMD.

In our present study, we have detected a decreased FMD in patients with erectile dysfunction. This is in agreement with previous studies, where a positive correlation was demonstrated between the magnitude of endothelial function, assessed by the flow-mediated brachial artery dilation and ED, characterized by the IIEF score $[66,67]$. Kaya et al. also demonstrated that endothelial function was impaired in patients with ED and the magnitude of FMD in ED patients presented in our study was similar to their findings [68]. In our study, we have demonstrated a negative correlation between FMD values and age or smoking. Aging is an important risk factor for ED, and it has been estimated that 55\% of men have ED at the age of 75 [7] . Recently it has been shown that FMD decreased with increasing age in men up to 70 years [69]. Moreover, cigarette smoking-induced ED in human is associated with impaired arterial flow to the penis, impaired endothelial function and smoking cessation led to prolonged improvements in endothelial function measured as increase in FMD [70-73]. In our study, we could not detect correlation between decreased FMD and cholesterol / triglyceride level. Kovacs and co-workers found a correlation between decreased endothelial function and $\mathrm{ED}$, however the severity of $\mathrm{ED}$ was independent on serum total cholesterol or triglyceride level, suggesting that these factors are unlikely have role in the observed differences in erectile function [66] . 


\subsection{Importance of EDH in erectile function}

The endothelium is an important contributor to smooth muscle relaxation of corpus cavernosum and penile small arteries, and is thought to play an important role in erection $[3,74]$ and erectile dysfunction [75]. Acetylcholine (ACh)-evoked endothelium-dependent vasodilation is thought to depend on nitric oxide (NO), prostanoids as a well as a nonNO/non-prostanoid endothelium-derived hyperpolarization (EDH) [76]. The EDH-type relaxation is present in human [30,33], horse [10], bovine [77], and rat [9] penile arteries. In systemic arteries several candidates for EDHF have been suggested, including potassium ions [34], products of the cytochrome P450 pathway [35-38], C-type natriuretic peptide (CNP) [39], and, controversially, hydrogen peroxide $[40,41]$. Both $\mathrm{K}^{+}$and $\mathrm{CNP}$ are believed to activate the $\mathrm{Na}^{+} / \mathrm{K}^{+}$-ATPase and/or inward rectifier $\mathrm{K}^{+}$channels in vascular smooth muscle layer $[34,39]$. Other studies have attributed agonist-evoked non-NO/nonprostanoid relaxation to communication by myoendothelial gap junctions [78-80]. In human penile arteries inhibition of the $\mathrm{P} 450$ enzyme causes marginal reduction of EDH-type relaxation [30], while inhibition of $\mathrm{Na}^{+} / \mathrm{K}^{+}$-ATPase have a marked effect in horse penile arteries [10]. Therefore, several mechanisms and candidates may contribute to EDH-type vasodilation in penile arteries.

In our studies, similarly to previous studies $[30,33]$, inhibition of NO synthase and cyclooxygenase caused a rightward shift in concentration-response curves for ACh suggesting that $\mathrm{NO}$ and vasodilator prostanoids contribute to the endothelium dependent vasodilation to ACh in human penile arteries. However, in the presence of inhibitors of NO synthase and cyclooxygenase, considerable ACh relaxation persisted. Our findings agree with previous studies in penile arteries from man $[30,33]$ and different animal species $[9,10]$ where endothelium-dependent agonists such as bradykinin and ACh also evoked pronounced vasodilation in the presence of inhibitors of NO synthase and cyclooxygenase. These findings suggest that in addition to NO and prostanoids, a non-NO nonprostanoid EDH-type relaxation is involved in ACh relaxation. Our study provides direct evidence that ACh actually causes endothelium dependent hyperpolarization in human penile arteries, a finding which, for the first time, substantiates that an EDH contributes to the responses to ACh in human penile arteries. 
In systemic arteries the EDH-type relaxation is dependent on activation of endothelial small-and intermediate conductance calcium-activated $\mathrm{K}^{+}$channels which can be blocked by the combination of apamin and charybdotoxin, respectively $[34,81,82]$. Combination of apamin and charybdotoxin, which blocks calcium-activated $\mathrm{K}^{+}$channels, has been found to inhibit ACh relaxation in human penile arteries [30]. In the present study, the combination of apamin and charybdotoxin also inhibited the EDH-type relaxation evoked by ACh in human penile small arteries, thus confirming the presence of an EDH. This was further substantiated by the use of the combination of barium and ouabain which was found to block the effect of EDH in rat mesenteric arterial smooth muscle [34], and also markedly inhibited EDH-type relaxation in horse penile arteries [10]. In our study the combination of barium and ouabain also inhibited ACh relaxation suggesting that an EDH mediates the vasodilation.

\subsection{CNP and EDH in penile arteries}

As mentioned in previous chapter, several candidates may contribute to EDHF-type relaxation in penile arteries $[10,30]$. CNP is a likely candidate for an EDHF in human penile arteries. First, CNP receptors are present in the corpus cavernosum of different species [8385 ]. Second the EDHF-type relaxation regulates neurogenic contraction [9], an observation which is in agreement with the recent demonstration of both pre- and postjunctional CNP receptors in arteries [86]. Third, in the present study, CNP evoked relaxations in the presence of inhibitors of NO synthase and cyclooxygenase and in arteries without endothelium. All these findings agree with CNP being an EDHF in human penile arteries, although further studies are required where release of CNP from endothelial cells is measured. However, because of the size of the penile arteries, such measurements are excluded with the currently available methods.

CNP has previously been described to cause hyperpolarization in rat mesenteric and porcine coronary arteries $[39,87]$. CNP evoked hyperpolarization of human penile arterial smooth muscle, similarly to ACh, thereby providing direct evidence that it possesses an important characteristic of an EDHF. However, CNP induced less hyperpolarization compared to $\mathrm{ACh}$, suggesting that in addition to $\mathrm{CNP}$, other candidates may also contribute to ACh-evoked EDH responses in human penile arteries. The biological activity of CNP can be 
mediated both by activation of of natriuretic peptide receptor (NPR)-B [88] or NPR-C [89] . The selective NPR-C agonist, $\mathrm{cANF}_{4-23}$, induced relaxations suggesting the presence of NPR$\mathrm{C}$ receptors in human penile small arteries. In rat mesenteric small arteries, the NPR-C was suggested to be linked to activation of the smooth muscle inward rectifier $\mathrm{K}^{+}$channel and to mediate EDHF-type relaxation $[39,89]$, and hence activation of NPR-C may contribute to CNP relaxation in human penile small arteries. However, CNP relaxation is more potent and pronounced compared with $\mathrm{cANF}_{4-23}$, suggesting that activation of NPR-B also contributes to CNP relaxation in human penile arteries. NPR-B is present in the corpus cavernosum of different species including man [83-85], and is linked to particulate guanylyl cyclase and the formation of cyclic guanosine monophosphate (GMP) [90]. Activation of the cyclic GMP pathway has been found to lead to activation of both $\mathrm{Na}^{+} / \mathrm{K}^{+}$-ATPase and $\mathrm{BK}$ Ca in horse penile arteries $[10,11]$, and of $\mathrm{Na}^{+} / \mathrm{K}^{+}$-ATPase in human corpus cavernosum [91]. Moreover, CNP evoked relaxation in systemic arteries was described to be inhibited by iberiotoxin, a blocker of $\mathrm{BK}_{\mathrm{Ca}}$ channels, [92-95]. In our investigations, both a blocker of intermediate-conductance $\mathrm{Ca}^{2+}$ - activated $\mathrm{K}^{+}$channels and $\mathrm{BK}_{\mathrm{Ca}}$ channels, charybdotoxin, and iberitoxin markedly reduced CNP relaxation suggesting $\mathrm{BK}_{\mathrm{Ca}}$ channels are involved in $\mathrm{CNP}$ relaxation. Addition of apamin plus charybdotoxin did not cause further inhibition compared to charybdotoxin alone, hence excluding a contribution of small-conductance $\mathrm{Ca}^{2+}$-activated $\mathrm{K}^{+}$channels to CNP relaxation. Therefore, together with the pronounced effect of barium and ouabain, the inhibitory effect of iberiotoxin makes it plausible that CNP causes relaxation in human penile arteries through activation of NPR-B and NPR-C followed, respectively, by the activation of iberiotoxin-sensitive $\mathrm{BK}_{\mathrm{Ca}}$ channels and $\mathrm{Na}^{+} / \mathrm{K}^{+}$-ATPase, and by the activation of barium-sensitive inward rectifier $\mathrm{K}^{+}$channels.

\subsection{Importance of $\mathrm{BK}_{\mathrm{Ca}}$ channels in erectile function}

The presence of large conductance $\mathrm{Ca}^{2+}$-activated $\mathrm{K}^{+}\left(\mathrm{BK}_{\mathrm{Ca}}\right)$ current has been shown in isolated smooth muscle cells obtained from human corpus cavernosum with electrophysiological recordings $[44,45,96-98]$ and the functional role of $\mathrm{BK}_{\mathrm{Ca}}$ channel was also demonstrated in human corpus cavernosum smooth muscle strips [49,98]. Activation of $\mathrm{BK}_{\mathrm{Ca}}$ channels hyperpolarizes the smooth muscle cell membrane leading to vasodilatation 
of penile arteries and relaxation of corpora cavernosa [14]. $\mathrm{BK}_{\mathrm{Ca}}$ channels are directly involved in the modulation of myogenic tone in rat intracavernous artery [9], in the vasorelaxant effect of sildenafil in horse penile resistance arteries [99], and in the flowevoked vasodilation in rat penile dorsal arteries [100]. However, there is limited information concerning a functional role for $\mathrm{BK}_{\mathrm{Ca}}$ channels in the regulation of tone in human penile arteries. In our study, iberiotoxin, a selective $\mathrm{BK}_{\mathrm{Ca}}$ channel blocker, inhibited the endothelium-dependent, acetylcholine-evoked vasodilatations both in the absence and presence of L-NAME and INDO (inhibitors of nitric oxide synthase and cyclooxigenase, respectively), suggesting the important role of $\mathrm{BK}_{\mathrm{Ca}}$ channel in regulation of human penile vascular tone. This is in agreement with our previus findings that iberiotoxin enhanced the basal unstimulated tone and reduced the C-type natriuretic peptide-evoked relaxation in human intracavernous arterial preparations [101] .

Role of $\mathrm{BK}_{\mathrm{Ca}}$ channels in NO- and $\mathrm{EDH}$-evoked vasorelaxation has been demonstrated in various systemic arteries obtained from different species $[47,102]$. BK $\mathrm{Ca}$ channel located in vascular smooth muscle cells modulates endothelial cell outward current and NO release and vasorelaxation [103] and they are also involved in nitrergic vasodilatation in horse penile arteries [11]. Moreover $\mathrm{BK}_{\mathrm{Ca}}$ channel is a major target in the vasodilator response of different substances, such as NO [104], prostanoids [45, 105], hydrogen peroxide [106], and CNP [101] however most of these studies were performed in systemic arteries. Involvement of $\mathrm{BK}_{\mathrm{Ca}}$ channels in $\mathrm{NO} /$ prostanoid/EDH-type relaxation has been described in penile corporal smooth muscle obtained from rat [107] and human $[45,97]$ and in penile small arteries isolated from rat $[100,108]$ and horse [99]. In our study, we have demonstrated for the first time, that $\mathrm{BK}_{\mathrm{Ca}}$ channel, sensitive to iberiotoxin, plays an important role in both NO-mediated and EDH-type relaxation of human intracavernous arteries.

\subsection{BKCa channel as target for the treatment of erectile dysfunction}

Consistent with the importance of $\mathrm{BK}_{\mathrm{Ca}}$ channels in smooth muscle relaxation, corpus cavernosum strips obtained from $\mathrm{BK}_{\mathrm{Ca}}$ channel knockout mice showed reduced ability to relax in response to electric stimulation of nonadrenergic-noncholinergic (NANC) nerves [109]. In addition to these in vitro experiments, nerve stimulation induced increases 
in intracavernosal pressure were reduced in $\mathrm{BK}_{\mathrm{Ca}}$ channel knockout mice in vivo [109]. These results clearly indicate that loss of the $\mathrm{BK}_{\mathrm{Ca}}$ channel leads to erectile dysfunction. Conversely, elevation of $\mathrm{BK}_{\mathrm{Ca}}$ channel expression supports the idea that erectile function can be also improved. Supporting this view, intracavernosal injection of cloned DNA encoding the human $\mathrm{BK}_{\mathrm{Ca}}$ channel led to reversal of erectile dysfunction induced by age $[110,111]$, diabetes [112] and atherosclerosis [113]. In 2006, a human safety and tolerability phase I study was performed with intracavernosal injection of the cloned gene hSlo (for human slowpoke), which encodes the pore-forming subunit of the $\mathrm{BK}_{\mathrm{Ca}}$ channel. In this study, promising primary safety outcomes were demonstrated and two of the men participating in the study responded with improved erectile function [114]. However, despite the promising primary safety outcomes of the study, no further studies have been reported.

Opening of $\mathrm{BK}_{\mathrm{Ca}}$ channels would be an alternative way of restoring an insufficient erectile function. Numerous $\mathrm{BK}_{\mathrm{Ca}}$ channel activators have been identified, including the synthetic benzimidazolone derivatives (e.g., NS004 and NS1619), the biarylureas (e.g., NS1608), the aryloxindoles (e.g., BMS-204352), quinolinones and the natural modulators (e.g., dihydrosoyasaponin-1 and flavanoids) [115-118] . Although these agents activate $\mathrm{BK}_{\mathrm{Ca}}$ channels, they also display additional nonspecific effects, like inhibition of $\mathrm{Ca}^{2+}$ currents and voltage-activated $\mathrm{K}^{+}$channels [119]. Due to their unspecific effects, $\mathrm{BK}_{\mathrm{Ca}}$ channel openers were not suitable drugs to investigate erectile function in vivo. Evidences are accumulating to suggest that newer $\mathrm{BK}_{\mathrm{Ca}}$ channel openers facilitates erectile responses in vivo $[49,116-$ 118]. However, so far no successful clinical results have been published. NS11021 (1-(3,5Bis trifluoromethyl-phenyl)-3-[4-bromo-2-(1H-tetrazol-5-yl)-phenyl]-thiourea), a novel selective opener of this channel acivated $\mathrm{BK}_{\mathrm{Ca}}$ channels concentration-dependent manner at micromolar concentration without modulating $\mathrm{Kv}$ (except $\mathrm{Kv} 7.4$ ), $\mathrm{Na}^{+}$, and $\mathrm{Ca}^{2+}$ currents [120]. NS11021 caused relaxation of both intracavernosal arteries and corpus cavernosum strips obtained from rat and human and it was also effective in facilitating erectile responses in anesthetized rats [49]. In our studies we have demonstrated the importance of $\mathrm{BK}_{\mathrm{Ca}}$ channels in both endothelium-dependent and -independent relaxation of intracavernous arteries. Relaxation of intracavernous and helicine arteries is a key step in the erectile process resulting in increased arterial blood flow into the corpora cavernosa and is followed by 
relaxation of cavernosal smooth muscle. These results clearly suggest a potential for use of $\mathrm{BK}_{\mathrm{Ca}}$ openers in the treatment of erectile dysfunction.

An apparent limitation of the samples examined in the our study could be that they were obtained from patients undergoing transsexual operations, and we cannot entirely exclude that hormonal treatments influence the endothelial responses. However, the advantage, on the other hand, is none of the patients had cardiovascular disease, which is known to alter endothelium-dependent vasodilation in penile arteries [121-123]. Vascular diseases with augmented contractility and/or impaired relaxation of arterial and corporal smooth muscle are the most common causes of erectile dysfunction. Thus, in erectile tissue and penile arteries from patients with diabetes, endothelium dependent relaxation is blunted $[30,124]$, as well as in penile arteries and erectile tissue isolated from hypertensive and diabetic animals $[125,126]$. Phosphodiesterase type 5 inhibitors are the basic treatment of erectile dysfunction, but they are less efficient in patients with diabetes [127]. The fact that $\mathrm{BK}_{\mathrm{Ca}}$ channels play a key role in regulation of vascular function in our studies is consistent with previous findings showing enhanced erectile response after administration of $\mathrm{BK}_{\mathrm{Ca}}$ channel openers in vivo [49]. Therefore, activators of $\mathrm{BK}_{\mathrm{Ca}}$ channels may have a therapeutic potential in the treatment of erectile dysfunction.

\section{Acknowledgments}

This work was supported by research grants from OTKA.

I am grateful to Prof. Zoltán Bajory, Prof. László Pajor, Attila Kun, Éva Jebelovszky for their help. Finally, but first of all I would like to thank to my family for providing a steady background to my work. 
1 Andersson KE. Mechanisms of penile erection and basis for pharmacological treatment of erectile dysfunction. Pharmacol Rev 2011; 63: 811-859

2 Andersson KE, Wagner G. Physiology of penile erection. Physiol Rev 1995; 75: 191236

3 Simonsen U, Garcia-Sacristan A, Prieto D. Penile arteries and erection. J Vasc Res 2002; 39: 283-303

4 Argiolas A, Melis MR. Central control of penile erection: role of the paraventricular nucleus of the hypothalamus. Prog Neurobiol 2005; 76: 1-21

5 Melis MR, Argiolas A. Central control of penile erection: a re-visitation of the role of oxytocin and its interaction with dopamine and glutamic acid in male rats. Neurosci Biobehav Rev 2011; 35: 939-955

6 Montorsi F, Sarteschi M, Maga T et al. Functional anatomy of cavernous helicine arterioles in potent subjects. J Urol 1998; 159: 808-810

7 Melman A, Gingell JC. The epidemiology and pathophysiology of erectile dysfunction. J Urol 1999; 161: 5-11

8 Hill MA, Meininger GA, Davis MJ et al. Therapeutic potential of pharmacologically targeting arteriolar myogenic tone. Trends Pharmacol Sci 2009; 30: 363-374

9 Kun A, Martinez AC, Tanko LB et al. Ca2+-activated K+ channels in the endothelial cell layer involved in modulation of neurogenic contractions in rat penile arteries. Eur $J$ Pharmacol 2003; 474: 103-115

10 Prieto D, Simonsen U, Hernandez M et al. Contribution of K+ channels and ouabainsensitive mechanisms to the endothelium-dependent relaxations of horse penile small arteries. Br J Pharmacol 1998; 123: 1609-1620

11 Simonsen U, Prieto D, Sanez dT, I et al. Involvement of nitric oxide in the nonadrenergic non-cholinergic neurotransmission of horse deep penile arteries: role of charybdotoxin-sensitive K(+)-channels. Br J Pharmacol 1995; 116: 2582-2590

12 Giuliano F, Bernabe J, Jardin A et al. Antierectile role of the sympathetic nervous system in rats. J Urol 1993; 150: 519-524

13 Saenz dT, I, Kim N, Lagan I et al. Regulation of adrenergic activity in penile corpus cavernosum. J Urol 1989; 142: 1117-1121

14 Prieto D. Physiological regulation of penile arteries and veins. Int J Impot Res 2008; 20: $17-29$ 
15 Minhas S, Cartledge J, Eardley I. The role of prostaglandins in penile erection. Prostaglandins Leukot Essent Fatty Acids 2000; 62: 137-146

16 Holmquist F, Kirkeby HJ, Larsson B et al. Functional effects, binding sites and immunolocalization of endothelin-1 in isolated penile tissues from man and rabbit. $J$ Pharmacol Exp Ther 1992; 261: 795-802

17 Andersson KE. Pharmacology of penile erection. Pharmacol Rev 2001; 53: 417-450

18 Kifor I, Williams GH, Vickers MA et al. Tissue angiotensin II as a modulator of erectile function. I. Angiotensin peptide content, secretion and effects in the corpus cavernosum. J Urol 1997; 157: 1920-1925

19 Becker AJ, Uckert S, Stief CG et al. Possible role of bradykinin and angiotensin II in the regulation of penile erection and detumescence. Urology 2001; 57: 193-198

20 Burnett AL, Lowenstein CJ, Bredt DS et al. Nitric oxide: a physiologic mediator of penile erection. Science 1992; 257: 401-403

21 Dail WG, Barba V, Leyba L et al. Neural and endothelial nitric oxide synthase activity in rat penile erectile tissue. Cell Tissue Res 1995; 282: 109-116

22 Hedlund P, Alm P, Andersson KE. NO synthase in cholinergic nerves and NOinduced relaxation in the rat isolated corpus cavernosum. Br J Pharmacol 1999; 127: 349-360

23 Hedlund P, Ny L, Alm P et al. Cholinergic nerves in human corpus cavernosum and spongiosum contain nitric oxide synthase and heme oxygenase. J Urol 2000; 164: 868875

24 Tong YC, Broderick G, Hypolite $\mathbf{J}$ et al. Correlations of purinergic, cholinergic and adrenergic functions in rabbit corporal cavernosal tissue. Pharmacology 1992; 45: 241249

25 Wu HY, Broderick GA, Suh JK et al. Effects of purines on rabbit corpus cavernosum contractile activity. Int J Impot Res 1993; 5: 161-167

26 Busse R, Fleming I. Regulation of endothelium-derived vasoactive autacoid production by hemodynamic forces. Trends Pharmacol Sci 2003; 24: 24-29

27 Hurt KJ, Musicki B, Palese MA et al. Akt-dependent phosphorylation of endothelial nitric-oxide synthase mediates penile erection. Proc Natl Acad Sci U S A 2002; 99: 4061-4066

28 Angulo J, Cuevas P, La Fuente JM et al. Regulation of human penile smooth muscle tone by prostanoid receptors. Br J Pharmacol 2002; 136: 23-30 
29 Moreland RB, Albadawi H, Bratton C et al. O2-dependent prostanoid synthesis activates functional PGE receptors on corpus cavernosum smooth muscle. Am J Physiol Heart Circ Physiol 2001; 281: H552-H558

30 Angulo J, Cuevas P, Fernandez A et al. Calcium dobesilate potentiates endotheliumderived hyperpolarizing factor-mediated relaxation of human penile resistance arteries. Br J Pharmacol 2003; 139: 854-862

31 Edwards G, Feletou M, Weston AH. Endothelium-derived hyperpolarising factors and associated pathways: a synopsis. Pflugers Arch 2010; 459: 863-879

32 Shimokawa H, Yasutake H, Fujii K et al. The importance of the hyperpolarizing mechanism increases as the vessel size decreases in endothelium-dependent relaxations in rat mesenteric circulation. J Cardiovasc Pharmacol 1996; 28: 703-711

33 Simonsen U, Prieto D, Delgado JA et al. Nitric oxide is involved in the inhibitory neurotransmission and endothelium-dependent relaxations of human small penile arteries. Clin Sci (Lond) 1997; 92: 269-275

34 Edwards G, Dora KA, Gardener MJ et al. $\mathrm{K}+$ is an endothelium-derived hyperpolarizing factor in rat arteries. Nature 1998; 396: 269-272

35 Bauersachs J, Hecker M, Busse R. Display of the characteristics of endotheliumderived hyperpolarizing factor by a cytochrome P450-derived arachidonic acid metabolite in the coronary microcirculation. Br J Pharmacol 1994; 113: 1548-1553

36 Bolz SS, Fisslthaler B, Pieperhoff S $\boldsymbol{e t}$ al. Antisense oligonucleotides against cytochrome $\mathrm{P} 4502 \mathrm{C} 8$ attenuate $\mathrm{EDHF}$-mediated $\mathrm{Ca}(2+)$ changes and dilation in isolated resistance arteries. FASEB $J$ 2000; 14: 255-260

37 Fisslthaler B, Hinsch N, Chataigneau T et al. Nifedipine increases cytochrome $\mathrm{P} 4502 \mathrm{C}$ expression and endothelium-derived hyperpolarizing factor-mediated responses in coronary arteries. Hypertension 2000; 36: 270-275

38 Fulton D, McGiff JC, Quilley J. Contribution of NO and cytochrome P450 to the vasodilator effect of bradykinin in the rat kidney. Br J Pharmacol 1992; 107: 722-725

39 Chauhan SD, Nilsson H, Ahluwalia A et al. Release of C-type natriuretic peptide accounts for the biological activity of endothelium-derived hyperpolarizing factor. Proc Natl Acad Sci U S A 2003; 100: 1426-1431

40 Ellis A, Triggle CR. Endothelium-derived reactive oxygen species: their relationship to endothelium-dependent hyperpolarization and vascular tone. Can J Physiol Pharmacol 2003; 81: 1013-1028

41 Matoba T, Shimokawa H, Nakashima M et al. Hydrogen peroxide is an endotheliumderived hyperpolarizing factor in mice. J Clin Invest 2000; 106: 1521-1530 
42 Dalsgaard T, Kroigaard C, Simonsen U. Calcium-activated potassium channels - a therapeutic target for modulating nitric oxide in cardiovascular disease? Expert Opin Ther Targets 2010; 14: 825-837

43 Bolotina VM, Najibi S, Palacino JJ et al. Nitric oxide directly activates calciumdependent potassium channels in vascular smooth muscle. Nature 1994; 368: 850-853

44 Wang HZ, Lee SW, Christ GJ. Comparative studies of the maxi-K (K(Ca)) channel in freshly isolated myocytes of human and rat corpora. Int J Impot Res 2000; 12: 9-18

45 Lee SW, Wang HZ, Zhao W et al. Prostaglandin E1 activates the large-conductance KCa channel in human corporal smooth muscle cells. Int J Impot Res 1999; 11: 189-199

46 Eichhorn B, Dobrev D. Vascular large conductance calcium-activated potassium channels: functional role and therapeutic potential. Naunyn Schmiedebergs Arch Pharmacol 2007; 376: 145-155

47 Hu XQ, Zhang L. Function and regulation of large conductance $\mathrm{Ca}(2+)$-activated $\mathrm{K}(+)$ channel in vascular smooth muscle cells. Drug Discov Today 2012; 17: 974-987

48 Francis SH, Busch JL, Corbin JD et al. cGMP-dependent protein kinases and cGMP phosphodiesterases in nitric oxide and cGMP action. Pharmacol Rev 2010; 62: 525-563

49 Kun A, Matchkov VV, Stankevicius E et al. NS11021, a novel opener of largeconductance $\mathrm{Ca}(2+)$-activated $\mathrm{K}(+)$ channels, enhances erectile responses in rats. $\mathrm{Br} \mathrm{J}$ Pharmacol 2009; 158: 1465-1476

50 Waldkirch E, Uckert S, Yildirim H et al. Cyclic AMP-specific and cyclic GMPspecific phosphodiesterase isoenzymes in human cavernous arteries-immunohistochemical distribution and functional significance. World J Urol 2005; 23: 405-410

51 NIH Consensus Conference. Impotence. NIH Consensus Development Panel on Impotence. JAMA 1993; 270: 83-90

52 Feldman HA, Goldstein I, Hatzichristou DG et al. Impotence and its medical and psychosocial correlates: results of the Massachusetts Male Aging Study. J Urol 1994; 151: $54-61$

53 Ayta IA, McKinlay JB, Krane RJ. The likely worldwide increase in erectile dysfunction between 1995 and 2025 and some possible policy consequences. BJU Int 1999; 84: 50-56

54 Lue TF. Erectile dysfunction. $N$ Engl J Med 2000; 342: 1802-1813

55 Feldman HA, Johannes CB, Derby CA et al. Erectile dysfunction and coronary risk factors: prospective results from the Massachusetts male aging study. Prev Med 2000; 30: $328-338$ 
56 Stoner L, Sabatier MJ. Use of ultrasound for non-invasive assessment of flowmediated dilation. J Atheroscler Thromb 2012; 19: 407-421

57 Green DJ, Jones H, Thijssen D et al. Flow-mediated dilation and cardiovascular event prediction: does nitric oxide matter? Hypertension 2011; 57: 363-369

58 Montorsi P, Montorsi F, Schulman CC. Is erectile dysfunction the "tip of the iceberg" of a systemic vascular disorder? Eur Urol 2003; 44: 352-354

59 Solomon H, DeBusk RF, Jackson G. Erectile dysfunction: the need to be evaluated, the right to be treated. Am Heart J 2005; 150: 620-626

60 Gandaglia G, Salonia A, Passoni N et al. Erectile dysfunction as a cardiovascular risk factor in patients with diabetes. Endocrine 2012;

61 McVary KT. Clinical practice. Erectile dysfunction. N Engl J Med 2007; 357: 24722481

62 Gupta M, Kovar A, Meibohm B. The clinical pharmacokinetics of phosphodiesterase5 inhibitors for erectile dysfunction. J Clin Pharmacol 2005; 45: 987-1003

63 Hatzimouratidis K, Hatzichristou DG. Looking to the future for erectile dysfunction therapies. Drugs 2008; 68: 231-250

64 Hatzimouratidis K, Amar E, Eardley I et al. Guidelines on male sexual dysfunction: erectile dysfunction and premature ejaculation. Eur Urol 2010; 57: 804-814

65 Vlachopoulos C, Ioakeimidis N, Rokkas K et al. Cardiovascular effects of phosphodiesterase type 5 inhibitors. J Sex Med 2009; 6: 658-674

66 Kovacs I, Csaszar A, Toth J et al. Correlation between flow-mediated dilation and erectile dysfunction. J Cardiovasc Pharmacol 2008; 51: 148-153

67 Yavuzgil O, Altay B, Zoghi M et al. Endothelial function in patients with vasculogenic erectile dysfunction. Int J Cardiol 2005; 103: 19-26

68 Kaya C, Uslu Z, Karaman I. Is endothelial function impaired in erectile dysfunction patients? Int J Impot Res 2006; 18: 55-60

69 Skaug EA, Aspenes ST, Oldervoll L et al. Age and gender differences of endothelial function in 4739 healthy adults: the HUNT3 Fitness Study. Eur J Prev Cardiol 2012;

70 Tostes RC, Carneiro FS, Lee AJ et al. Cigarette smoking and erectile dysfunction: focus on NO bioavailability and ROS generation. J Sex Med 2008; 5: 1284-1295

71 Shiri R, Hakama M, Hakkinen J et al. Relationship between smoking and erectile dysfunction. Int J Impot Res 2005; 17: 164-169 
72 Johnson HM, Gossett LK, Piper ME et al. Effects of smoking and smoking cessation on endothelial function: 1-year outcomes from a randomized clinical trial. $\mathrm{J} \mathrm{Am} \mathrm{Coll}$ Cardiol 2010; 55: 1988-1995

73 Gul I, Karapinar H, Yarlioglues M et al. Acute effects of passive smoking on endothelial function. Angiology 2011; 62: 245-247

74 Saenz dT, I, Angulo J, Cellek S et al. Physiology of erectile function. J Sex Med 2004; 1: $254-265$

75 Saenz dT, I, Angulo J, Cellek S et al. Pathophysiology of erectile dysfunction. J Sex Med 2005; 2: 26-39

76 Busse R, Edwards G, Feletou M et al. EDHF: bringing the concepts together. Trends Pharmacol Sci 2002; 23: 374-380

77 Simonsen U, Contreras J, Garcia-Sacristan A et al. Effect of sildenafil on nonadrenergic non-cholinergic neurotransmission in bovine penile small arteries. Eur $J$ Pharmacol 2001; 412: 155-169

78 Chaytor AT, Evans WH, Griffith TM. Central role of heterocellular gap junctional communication in endothelium-dependent relaxations of rabbit arteries. $J$ Physiol 1998; 508 ( Pt 2): 561-573

79 Coleman HA, Tare M, Parkington HC. K+ currents underlying the action of endothelium-derived hyperpolarizing factor in guinea-pig, rat and human blood vessels. J Physiol 2001; 531: 359-373

80 Yamamoto Y, Imaeda K, Suzuki H. Endothelium-dependent hyperpolarization and intercellular electrical coupling in guinea-pig mesenteric arterioles. J Physiol 1999; 514 (Pt 2): 505-513

81 Buus NH, Simonsen U, Pilegaard HK et al. Nitric oxide, prostanoid and non-NO, nonprostanoid involvement in acetylcholine relaxation of isolated human small arteries. $\mathrm{Br}$ J Pharmacol 2000; 129: 184-192

82 Zygmunt PM, Hogestatt ED. Role of potassium channels in endothelium-dependent relaxation resistant to nitroarginine in the rat hepatic artery. Br J Pharmacol 1996; 117: 1600-1606

83 Guidone G, Muller D, Vogt K et al. Characterization of VIP and PACAP receptors in cultured rat penis corpus cavernosum smooth muscle cells and their interaction with guanylate cyclase-B receptors. Regul Pept 2002; 108: 63-72

84 Kim SZ, Kim SH, Park JK et al. Presence and biological activity of C-type natriuretic peptide-dependent guanylate cyclase-coupled receptor in the penile corpus cavernosum. J Urol 1998; 159: 1741-1746 
85 Kuthe A, Reinecke M, Uckert S et al. Expression of guanylyl cyclase B in the human corpus cavernosum penis and the possible involvement of its ligand C-type natriuretic polypeptide in the induction of penile erection. J Urol 2003; 169: 1918-1922

86 Grant S, Lutz EM, McPhaden AR et al. Location and function of VPAC1, VPAC2 and NPR-C receptors in VIP-induced vasodilation of porcine basilar arteries. J Cereb Blood Flow Metab 2006; 26: 58-67

87 Barton M, Beny JL, d'Uscio LV et al. Endothelium-independent relaxation and hyperpolarization to C-type natriuretic peptide in porcine coronary arteries. $J$ Cardiovasc Pharmacol 1998; 31: 377-383

88 Drewett JG, Fendly BM, Garbers DL et al. Natriuretic peptide receptor-B (guanylyl cyclase-B) mediates C-type natriuretic peptide relaxation of precontracted rat aorta. $J$ Biol Chem 1995; 270: 4668-4674

89 Villar IC, Panayiotou CM, Sheraz A et al. Definitive role for natriuretic peptide receptor-C in mediating the vasorelaxant activity of C-type natriuretic peptide and endothelium-derived hyperpolarising factor. Cardiovasc Res 2007; 74: 515-525

90 Potthast R, Potter LR. Phosphorylation-dependent regulation of the guanylyl cyclaselinked natriuretic peptide receptors. Peptides 2005; 26: 1001-1008

91 Gupta S, Moreland RB, Munarriz R et al. Possible role of $\mathrm{Na}(+)-\mathrm{K}(+)$-ATPase in the regulation of human corpus cavernosum smooth muscle contractility by nitric oxide. $\mathrm{Br}$ J Pharmacol 1995; 116: 2201-2206

92 Banks M, Wei CM, Kim CH et al. Mechanism of relaxations to C-type natriuretic peptide in veins. Am J Physiol 1996; 271: H1907-H1911

93 Garcha RS, Hughes AD. CNP, but not ANP or BNP, relax human isolated subcutaneous resistance arteries by an action involving cyclic GMP and BKCa channels. J Renin Angiotensin Aldosterone Syst 2006; 7: 87-91

94 Otsuka K, Tanaka H, Horinouchi T et al. Functional contribution of voltagedependent and $\mathrm{Ca} 2+$ activated $\mathrm{K}+(\mathrm{BK}(\mathrm{Ca}))$ channels to the relaxation of guinea-pig aorta in response to natriuretic peptides. J Smooth Muscle Res 2002; 38: 117-129

95 Tolsa JF, Gao Y, Sander FC et al. Differential responses of newborn pulmonary arteries and veins to atrial and C-type natriuretic peptides. Am J Physiol Heart Circ Physiol 2002; 282: H273-H280

96 Christ GJ, Spray DC, Brink PR. Characterization of K currents in cultured human corporal smooth muscle cells. J Androl 1993; 14: 319-328

97 Lee SW, Kang TM. Effects of nitric oxide on the Ca2+-activated potassium channels in smooth muscle cells of the human corpus cavernosum. Urol Res 2001; 29: 359-365 
98 Spektor M, Rodriguez R, Rosenbaum RS et al. Potassium channels and human corporeal smooth muscle cell tone: further evidence of the physiological relevance of the Maxi-K channel subtype to the regulation of human corporeal smooth muscle tone in vitro. J Urol 2002; 167: 2628-2635

99 Prieto D, Rivera L, Benedito S et al. $\mathrm{Ca} 2+$-activated $\mathrm{K}+(\mathrm{KCa})$ channels are involved in the relaxations elicited by sildenafil in penile resistance arteries. Eur J Pharmacol 2006; 531: 232-237

100 Schjorring O, Kun A, Flyvbjerg A et al. Flow-evoked vasodilation is blunted in penile arteries from Zucker diabetic fatty rats. J Sex Med 2012; 9: 1789-1800

101 Kun A, Kiraly I, Pataricza J et al. C-type natriuretic peptide hyperpolarizes and relaxes human penile resistance arteries. J Sex Med 2008; 5: 1114-1125

102 Tanaka Y, Koike K, Toro L. MaxiK channel roles in blood vessel relaxations induced by endothelium-derived relaxing factors and their molecular mechanisms. J Smooth Muscle Res 2004; 40: 125-153

103 Climent B, Schubert R, Stankevicius E et al. Large conductance Ca2+-activated K+ channels modulate endothelial cell outward currents and nitric oxide release in the intact rat superior mesenteric artery. Biochem Biophys Res Commun 2012; 417: 1007-1013

104 Robertson BE, Schubert R, Hescheler J et al. cGMP-dependent protein kinase activates Ca-activated $\mathrm{K}$ channels in cerebral artery smooth muscle cells. Am J Physiol 1993; 265: C299-C303

105 Ahn DS, Kim YB, Lee YH et al. Fatty acids directly increase the activity of $\mathrm{Ca}(2+)$ activated K+ channels in rabbit coronary smooth muscle cells. Yonsei Med J 1994; 35: $10-24$

106 Barlow RS, White RE. Hydrogen peroxide relaxes porcine coronary arteries by stimulating BKCa channel activity. Am J Physiol 1998; 275: H1283-H1289

107 Yousif MH, Benter IF. Role of cytochrome P450 metabolites of arachidonic acid in regulation of corporal smooth muscle tone in diabetic and older rats. Vascul Pharmacol 2007; 47: 281-287

108 Sanchez A, Villalba N, Martinez AC et al. Mechanisms of the relaxant effect of vardenafil in rat penile arteries. Eur J Pharmacol 2008; 586: 283-287

109 Werner ME, Zvara P, Meredith AL et al. Erectile dysfunction in mice lacking the large-conductance calcium-activated potassium (BK) channel. J Physiol 2005; 567: 545556

110 Christ GJ, Rehman J, Day N et al. Intracorporal injection of hSlo cDNA in rats produces physiologically relevant alterations in penile function. Am J Physiol 1998; 275: H600-H608 
111 Melman A, Zhao W, Davies KP et al. The successful long-term treatment of age related erectile dysfunction with hSlo cDNA in rats in vivo. $J$ Urol 2003; 170: 285-290

112 Christ GJ, Day N, Santizo C et al. Intracorporal injection of hSlo cDNA restores erectile capacity in STZ-diabetic F-344 rats in vivo. Am J Physiol Heart Circ Physiol 2004; 287: H1544-H1553

113 Christ GJ, Andersson KE, Williams K et al. Smooth-muscle-specific gene transfer with the human maxi-k channel improves erectile function and enhances sexual behavior in atherosclerotic cynomolgus monkeys. Eur Urol 2009; 56: 1055-1066

114 Melman A, Bar-Chama N, McCullough A et al. hMaxi-K gene transfer in males with erectile dysfunction: results of the first human trial. Hum Gene Ther 2006; 17: 11651176

115 Ghatta S, Nimmagadda D, Xu X et al. Large-conductance, calcium-activated potassium channels: structural and functional implications. Pharmacol Ther 2006; 110: 103-116

116 Boy KM, Guernon JM, Sit SY et al. 3-Thio-quinolinone maxi-K openers for the treatment of erectile dysfunction. Bioorg Med Chem Lett 2004; 14: 5089-5093

117 Hewawasam P, Fan W, Cook DA et al. 4-Aryl-3-(mercapto)quinolin-2-ones: novel maxi-K channel opening relaxants of corporal smooth muscle. Bioorg Med Chem Lett 2004; 14: 4479-4482

118 Hewawasam P, Fan W, Ding M et al. 4-Aryl-3-(hydroxyalkyl)quinolin-2-ones: novel maxi-K channel opening relaxants of corporal smooth muscle targeted for erectile dysfunction. J Med Chem 2003; 46: 2819-2822

119 Holland M, Langton PD, Standen NB et al. Effects of the BKCa channel activator, NS1619, on rat cerebral artery smooth muscle. Br J Pharmacol 1996; 117: 119-129

120 Bentzen BH, Nardi A, Calloe K et al. The small molecule NS11021 is a potent and specific activator of $\mathrm{Ca} 2+$-activated big-conductance $\mathrm{K}+$ channels. Mol Pharmacol 2007; 72: 1033-1044

121 Hannan JL, Heaton JP, Adams MA. Recovery of erectile function in aging hypertensive and normotensive rats using exercise and caloric restriction. $J$ Sex Med 2007; 4: 886-897

122 Wingard C, Fulton D, Husain S. Altered penile vascular reactivity and erection in the Zucker obese-diabetic rat. J Sex Med 2007; 4: 348-362

123 Xie D, Odronic SI, Wu F et al. A mouse model of hypercholesterolemia-induced erectile dysfunction. J Sex Med 2007; 4: 898-907 
124 Saenz dT, I, Goldstein I, Azadzoi K et al. Impaired neurogenic and endotheliummediated relaxation of penile smooth muscle from diabetic men with impotence. $N$ Engl J Med 1989; 320: 1025-1030

125 Angulo J, Cuevas P, Gabancho S et al. Enhancement of both EDHF and NO/cGMP pathways is necessary to reverse erectile dysfunction in diabetic rats. $J$ Sex Med 2005; 2: 341-346

126 Martinez AC, Stankevicius E, Jakobsen P et al. Blunted non-nitric oxide vasodilatory neurotransmission in penile arteries from renal hypertensive rats. Vascul Pharmacol 2006; 44: 354-362

127 Jackson G, Rosen RC, Kloner RA et al. The second Princeton consensus on sexual dysfunction and cardiac risk: new guidelines for sexual medicine. J Sex Med 2006; 3: 28-36 